University of Nebraska - Lincoln

DigitalCommons@University of Nebraska - Lincoln

Evaluation of Management Strategies for Bean Leaf Beetles (Coleoptera: Chrysomelidae) and Bean Pod Mottle Virus (Comoviridae) in Soybean

\author{
Jeffrey D. Bradshaw \\ lowa State University, jbradshaw2@unl.edu \\ Marlin E. Rice \\ lowa State University, marlinrice@gmail.com \\ John H. Hill \\ lowa State University, johnhill@iastate.edu
}

Follow this and additional works at: https://digitalcommons.unl.edu/panhandleresext

Part of the Agriculture Commons

Bradshaw, Jeffrey D.; Rice, Marlin E.; and Hill, John H., "Evaluation of Management Strategies for Bean Leaf Beetles (Coleoptera: Chrysomelidae) and Bean Pod Mottle Virus (Comoviridae) in Soybean" (2008). Panhandle Research and Extension Center. 40.

https://digitalcommons.unl.edu/panhandleresext/40

This Article is brought to you for free and open access by the Agricultural Research Division of IANR at DigitalCommons@University of Nebraska - Lincoln. It has been accepted for inclusion in Panhandle Research and Extension Center by an authorized administrator of DigitalCommons@University of Nebraska - Lincoln. 


\title{
Evaluation of Management Strategies for Bean Leaf Beetles (Coleoptera: Chrysomelidae) and Bean Pod Mottle Virus (Comoviridae) in Soybean
}

\author{
JEFFREY D. BRADSHAW, ${ }^{1,2}$ MARLIN E. RICE, ${ }^{1}$ AND JOHN H. HILL ${ }^{3}$
}

J. Econ. Entomol. 101(4): 1211-1227 (2008)

\begin{abstract}
Cerotoma trifurcata Förster (Coleoptera: Chrysomelidae) and Bean pod mottle virus (Comoviridae) (BPMV) both can reduce yield and seed quality of soybean, Glycine max (L.) Merr. Field experiments were conducted to evaluate the effects of systemic, seed-applied, and foliar-applied insecticides for the management of this pest complex at three locations in central, northeastern, and northwestern Iowa during 2002-2004. Seed-applied insecticide was evaluated according to a currently recommended management program for Iowa (i.e., insecticide applications that target emerging overwintered beetles, $\mathrm{F}_{0}$, and the first seasonal generation, $\mathrm{F}_{1}$ ). The experimental treatments included seed-applied (thiamethoxam, 0.3-0.5 g [AI] kg $\left.{ }^{-1}\right]$ or clothianidin, $47.32 \mathrm{ml}[\mathrm{AI}] \mathrm{kg}^{-1}$ ) and foliarapplied ( $\lambda$-cyhalothrin, 16.83-28.05 g [AI] ha ${ }^{-1}$ ) or esfenvalerate $\left(43.74-54.69 \mathrm{~g}[\mathrm{AI}] \mathrm{ha}^{-1}\right)$ insecticides. Applications of the foliar insecticides were timed to target $F_{0}, F_{1}$ or both $F_{0}$ and $F_{1}$ populations of $C$. trifurcata. Our results confirm that insecticides timed at $\mathrm{F}_{0}$ and $\mathrm{F}_{1}$ populations of C. trifurcata can reduce vector populations throughout the growing season, provide limited reduction in virus incidence, and improve both yield and seed coat color. Furthermore, seed-applied insecticides may be the more reliable option for an $\mathrm{F}_{0}$-targeted insecticide if used within this management strategy. An $\mathrm{F}_{0}$-targeted insecticide by itself only gave a yield improvement in one out of eight location-years. However, by adding an $\mathrm{F}_{1}$-targeted insecticide, there was a yield gain of $1.42-1.67$ quintal ha ${ }^{-1}$, based on contrast comparisons at three location-years.
\end{abstract}

KEY WORDS Cerotoma trifurcata, Glycine max, pest management, seed treatment

The adult bean leaf beetle, Cerotoma trifurcata Förster (Coleoptera: Chrysomelidae), causes economic damage to soybean, Glycine $\max (\mathrm{L}$.) Merr., by feeding on leaves, stems, and pods (Smelser and Pedigo 1992a, b, Pedigo and Zeiss 1996) and its pest status has been elevated further by its transmission of Bean pod mottle virus (Comoviridae) (BPMV) (Giesler et al. 2002). This virus reduces soybean yield (Horn et al. 1973, Hopkins and Mueller 1984) and grain quality (Hill et al. 2007). Furthermore, the effects of BPMV on soybean yield are synergistic with those of Soybean mosaic virus (SMV) (Ross 1968, Anjos et al. 1992), a seedand aphid-transmitted pathogen common in soybean (Steinlage et al. 2002).

Although transmitted by several species of Coleoptera (Horn et al. 1970, Patel and Pitre 1971, Fulton and Scott 1974, Mabry et al. 2003, Werner et al. 2003), BPMV is most efficiently transmitted by C. trifurcata, a species whose populations have undergone dramatic increases in abundance in recent years (Giesler et al. 2002). Recently, annual peak abundance at a single

\footnotetext{
${ }^{1}$ Department of Entomology, Iowa State University, Ames, IA 50011.

${ }^{2}$ Corresponding author, e-mail: bradshaw@iastate.edu.

${ }^{3}$ Department of Plant Pathology, Iowa State University, Ames, IA 50011
}

location in Iowa reached $\approx 96$ times the 1996 level (Bradshaw and Rice 2003). These changes in abundance are likely regional, and presumably the incidence and prevalence of BPMV has increased as a result. In Iowa, BPMV is ubiquitous (Krell et al. 2004) and apparently its prevalence and incidence is highest (Robertson and Nutter 2006) where C. trifurcata survival is highest (Rice and Pope 2004).

In Iowa, the bivoltine (Smelser and Pedigo 1991) $C$. trifurcata overwinter as adults (Kogan et al. 1974, Waldbauer and Kogan 1976, Smelser and Pedigo 1991), primarily in woodlots (Lam and Pedigo 2000), with three population maxima often observed (overwintered population, $\mathrm{F}_{0}$; first generation; $\mathrm{F}_{1}$; and second generation, $\mathrm{F}_{2}$ ). Although soybean is a preferred host (Henn 1989, Bradshaw et al. 2007), there are other hosts available to $C$. trifurcata before soybean emergence (Bradshaw et al. 2007). Hosts such as Desmodium spp. may be particularly important because they may be a prevalent source of inoculum for BPMV (Moore et al. 1969, Krell et al. 2003, Bradshaw et al. 2007). The early-season acquisition of virus may be influenced by its ability to remain viable within diapausing beetles or to be seed transmitted in soybean (Krell et al. 2003). Due to high transmission efficiency (Patel and Pitre 1976, Wang et al. 1992) and the pos- 
sibility that many adults may enter emergent soybean fields, early-season controls have been recommended (Krell et al. 2004).

Damage to soybean from C. trifurcata can be reduced by later planting (Pedigo and Zeiss 1996, Witkowski and Echtenkamp 1996), host plant resistance (Hammond et al. 2001, Lam and Pedigo 2001, Srinivas et al. 2001), or population suppression by chemical control (Lam et al. 2000, 2001). Management actions that affect a vector population can impact their transmissible agents (Perring et al. 1999); however, the affects of C. trifucata management on BPMV transmission are not fully understood. For example, preliminary studies indicate that early-planted soybean may have increased BPMV incidence (Giesler et al. 2002); however, in a 3-yr study, Krell et al. (2005) found that delayed soybean planting inconsistently reduced the seed-borne incidence of BPMV.

Various types of host plant resistance can reduce $C$. trifurcata injury to pods (Lam and Pedigo 2001) and leaves (Hammond et al. 2001, Srinivas et al. 2001). Although pathogen-derived resistance has been developed against BPMV (Reddy et al. 2001) and field tolerance may exist (Hill et al. 2007), no C. trifurcata resistance tool has been tested against BPMV.

The use of insecticides for the suppression of viral vectors has been tested in many crop systems with variable results. In virus pathosystems where management by insecticide application was attempted, 47\% have failed to reduce virus incidence (Perring et al. 1999). Although the insecticidal control of Coleoptera as viral vectors is poorly understood, insecticides are used commonly in soybean for the management of $C$. trifurcata, and, according to Krell et al. (2004), insecticidal control can reduce BPMV incidence if carefully timed against the appropriate adult beetle population. Krell et al. (2004) studied the impact of carefully timed chemical control of C. trifurcata and reported that a reduction in vector abundance reduced incidence of BPMV, improved yield, and could protect grain quality. This was particularly true for insecticides targeting $\mathrm{F}_{0}$ and $\mathrm{F}_{1}$ populations and has since been a recommended practice for soybean grown for food and seed in Iowa (Rice et al. 2007).

Some insecticides, such as the pyrethroid $\lambda$-cyhalothrin, suppress $C$. trifurcata abundance and have long residual activity (Hammond 1996), with an apparent antifeedant quality (Dobrin and Hammond $1985)$ in soybean. Additionally, $\lambda$-cyhalothrin can suppress $C$. trifurcata populations at low application rates (Rice and O'Neal 2007). For these reasons Krell et al. (2004) chose this chemical for C. trifurcata suppression to reduce the impact of virus on soybean. Importantly, Krell et al. (2004) also noted that insecticides must be applied as soon as adult $\mathrm{F}_{0}$ adults arrive in the field if the control is to be effective.

Regardless of pestiferous hazards, soybean growers desire varieties that tolerate early planting dates (for Iowa, this includes dates between late April to early May) with the expectation of improved or equivalent yield (Pedersen 2006). Because later planting is currently undesirable and cultivars with resistance to these pests (the beetle and pathogen) are not yet available to growers, insecticides have been used to manage this pest complex.

C. trifurcata can cause injury and transmit BPMV to soybean as soon as the plants emerge (Ross 1969, Walters 1970, Hopkins and Mueller 1984, Ragsdale 1984). However, spring rainfall may hinder proper timing of foliar-applied insecticides for suppression of early-season BPMV vectors. Systemic seed-applied insecticides may be effective for managing $F_{0}$ populations of $C$. trifurcata because of their efficacy at low application rates (M.E.R., unpublished data) and because they are applied to seed before planting. Additionally, neonicotinoids (e.g., thiamethoxam, imidacloprid, and clothianidin) are less toxic than foliarapplied insecticides to mammals, e.g., oral $\mathrm{LD}_{50}=$ 5,563 (Syngenta Crop Protection Inc. 2005), oral $\mathrm{LD}_{50} \leq 850$ (Bayer CropScience 2007), oral $\mathrm{LD}_{50} \leq$ 2,000 (Bayer CropScience 2006), and $\mathrm{LD}_{50}=351$ (Bayer CropScience 2006) mg/ kg of rat body weight, for thiamethoxam, imidacloprid, clothianidin, and $\lambda$-cyhalothrin, respectively, and predaceous Heteroptera (Boyd and Boethel 1998).

The objectives of this study were to evaluate $\mathrm{F}_{0}$ - and $\mathrm{F}_{1}$-targeted C. trifurcata chemical control tactics for the management of $C$. trifurcata and BPMV. The emphasis was to determine the effects a seed-applied insecticide might have on C. trifurcata populations and how this would affect BPMV incidence in soybean. These effects were tested relative to the recommended management strategy of Krell et al. (2004) (i.e., the application of an $\mathrm{F}_{0^{-}}+\mathrm{F}_{1^{-}}$targeted foliar insecticide).

\section{Materials and Methods}

Experimental Design. Field studies were geographically distributed at three locations in Iowa during 2002-2004. Experimental plots were located at northwest, northeast, and central Iowa State University Research and Demonstration Farms, in O'Brien, Floyd, and Story counties, respectively (subsequently referred to as northwest, northeast, and central). Northwest was abandoned in 2004 due to hail damage. Within each field, seven (2002) or eight (2003-2004) experimental treatments (Table 1) were applied in a randomized complete block design, with each experimental unit of $\approx 279 \mathrm{~m}^{2}$, composed of 12 rows (76.2-cm row spacing) of soybean, each $30.5 \mathrm{~m}$ long, having four (in 2002) or eight (in 2003-2004) replicates of Kruger 277 or Mark 0124 soybean cultivars (both are yellow seed-coat varieties), respectively. Both soybean cultivars were glyphosate resistant and soybean cyst nematode resistant; glyphosate herbicide was used as needed according to common weed management practices. To minimize interplot interference between experimental units, only the center six rows received an experimental treatment. Experimental blocks were separated by at least $9.14 \mathrm{~m}$ of untreated soybean. Insecticidal treatments were applied either to seed or foliage (Table 1) with foliar insecticides applied by tractor and boom sprayer at first sighting of 
Table 1. Experimental treatments for management of adult $C$. trifurcata and BPMV, 2002-2004

\begin{tabular}{|c|c|c|c|c|}
\hline $\begin{array}{l}\text { Experimental } \\
\text { treatment }\end{array}$ & Active ingredient & Application substrate (rate) & Formulation & $\begin{array}{c}\text { Pop } \\
\text { target }^{a}\end{array}$ \\
\hline \multicolumn{5}{|l|}{2002} \\
\hline 1 & Thiamethoxam & Seed $\left(0.3 \mathrm{~g}[\mathrm{AI}] \mathrm{kg}^{-1}\right)$ & Cruiser & $\mathrm{F}_{0}$ \\
\hline 2 & Clothianidin & Seed $\left(47.32 \mathrm{ml}[\mathrm{AI}] \mathrm{kg}^{-1}\right)$ & Poncho & $\mathrm{F}_{0}$ \\
\hline 3 & Thiamethoxam $+\lambda$-cyhalothrin & $\begin{array}{l}\text { Seed }\left(0.3 \mathrm{~g}[\mathrm{AI}] \mathrm{kg}^{-1}\right)+\text { foliage } \\
\quad\left(28.05 \mathrm{~g}[\mathrm{AI}] \mathrm{ha}^{-1}\right)\end{array}$ & Cruiser + Warrior & $\mathrm{F}_{0}+\mathrm{F}_{1}$ \\
\hline 4 & $\lambda$-Cyhalothrin & Foliage (16.83 g [AI] $\left.\mathrm{ha}^{-1}\right)$ & Warrior & $\mathrm{F}_{0}$ \\
\hline 5 & $\lambda$-Cyhalothrin & Foliage $\left(28.05 \mathrm{~g}[\mathrm{AI}] \mathrm{ha}^{-1}\right)$ & Warrior & $\mathrm{F}_{1}$ \\
\hline 6 & $\lambda$-Cyhalothrin & Foliage $\left(16.83 \mathrm{~g}[\mathrm{AI}] \mathrm{ha}^{-1}\right)+$ foliage & Warrior & $\mathrm{F}_{0}+\mathrm{F}_{1}$ \\
\hline 7 & Untreated control & $\left(28.05 \mathrm{~g}[\mathrm{AI}] \mathrm{ha}^{-1}\right)$ & & \\
\hline \multicolumn{5}{|l|}{2003 and 2004} \\
\hline 1 & Thiamethoxam & Seed $\left(0.5 \mathrm{~g}[\mathrm{AI}] \mathrm{kg}^{-1}\right)$ & Cruiser & $\mathrm{F}_{0}$ \\
\hline 2 & Thiamethoxam $+\lambda$-cyhalothrin & $\begin{array}{l}\text { Seed }\left(0.5 \mathrm{~g}[\mathrm{AI}] \mathrm{kg}^{-1}\right)+\text { foliage } \\
\quad\left(21.91 \mathrm{~g}[\mathrm{AI}] \mathrm{ha}^{-1}\right)\end{array}$ & Cruiser + Warrior & $\mathrm{F}_{0}+\mathrm{F}_{0}$ \\
\hline 3 & Thiamethoxam $+\lambda$-cyhalothrin & $\begin{array}{l}\text { Seed }\left(0.5 \mathrm{~g}[\mathrm{AI}] \mathrm{kg}^{-1}\right)+\text { foliage } \\
\quad\left(28.05 \mathrm{~g}[\mathrm{AI}] \mathrm{ha}^{-1}\right)\end{array}$ & Cruiser + Warrior & $\mathrm{F}_{0}+\mathrm{F}_{1}$ \\
\hline 4 & $\lambda$-Cyhalothrin & Foliage (21.91 g [AI] $\left.\mathrm{ha}^{-1}\right)$ & Warrior & $\mathrm{F}_{0}$ \\
\hline 5 & $\lambda$-Cyhalothrin & Foliage $\left(28.05 \mathrm{~g}[\mathrm{AI}] \mathrm{ha}^{-1}\right)$ & Warrior & $\mathrm{F}_{1}$ \\
\hline 6 & $\lambda$-Cyhalothrin & $\begin{array}{l}\left.\text { Foliage (21.91 g }[\mathrm{AI}] \mathrm{ha}^{-1}\right)+ \text { foliage } \\
\quad\left(28.05 \mathrm{~g}[\mathrm{AI}] \mathrm{ha}^{-1}\right)\end{array}$ & Warrior & $\mathrm{F}_{0}+\mathrm{F}_{1}$ \\
\hline 7 & Esfenvalerate & Foliage $\left(43.74 \mathrm{~g}[\mathrm{AI}] \mathrm{ha}^{-1}\right)+$ foliage & Asana & $\mathrm{F}_{0}+\mathrm{F}_{1}$ \\
\hline 8 & Untreated control & $\left(54.69 \mathrm{~g}[\mathrm{AI}] \mathrm{ha}^{-1}\right)$ & & \\
\hline
\end{tabular}

${ }^{a} \mathrm{~F}_{0}$, at arrival of overwintered C. trifurcata; $\mathrm{F}_{1}$, at emergence of first generation C. trifurcata.

$\mathrm{F}_{0}$ (around soybean stage VC-V1; Fehr et al. 1971) and $\mathrm{F}_{1}$ (around soybean stage V6-R1) beetles.

Among locations, planting dates ranged from 25 April to 7 May (2002), from 17 to 24 May (2003), and from 28 April to 3 May (2004). Although Krell et al. (2005) reported that variation in planting date had little effect on BPMV incidence, early planting dates were used to maximize $C$. trifurcata colonization of plots (Pedigo and Zeiss 1996) and to maximize the potential for early transmission of BPMV. These dates span early to normal planting times for soybean in Iowa (Pedersen 2006). Plant emergence was expected to coincide with $\mathrm{F}_{0}$ C. trifurcata immigration from overwintering sites (Smelser and Pedigo 1991).

Insect Sampling. C. trifurcata were sampled weekly from soybean emergence $(\mathrm{VE})$ until leaf drop $(\approx \mathrm{R} 7)$. Early-stage soybean was too short and delicate for sweep-net sampling; therefore, soybean stages VE-V4 were sampled by five in situ counts of a 5-m length of row per experimental unit. When plants reached stage V4-V5, 20-sweep sampling units were taken from the middle six rows in each experimental unit with a 38$\mathrm{cm}$-diameter sweep net, bagged, and returned to the laboratory for counting. Soybean development was estimated as described by Fehr et al. (1971). Relative emergence of adult beetles was determined by counting teneral individuals within sweep-net samples.

BPMV Incidence. Soybean was sampled for BPMV after the peak of the $\mathrm{F}_{0}, \mathrm{~F}_{1}$, and $\mathrm{F}_{2}$ C. trifurcata populations (three sampling times) in 2002: at the beginning and after the peak of each population (six sampling times) in 2003, at the beginning and after the peak of $F_{0}$ and $F_{1}$ populations, and at the beginning of $\mathrm{F}_{2}$ (four sampling times) population in 2004 . Samples were taken from the middle four rows of each treatment by systematically collecting, in $\approx 5$-m intervals, the uppermost, expanded leaves of 20 plants per treatment (five leaves from each sampling row). Leaves were collected into plastic bags, according to experimental unit, stored on ice and brought back to the laboratory. Sap was extracted from each leaf using a leaf grinder (Ravenel Specialties Corp., Seneca, SC) with phosphate-buffered saline $(0.05 \mathrm{M}$ sodium phosphate, $0.15 \mathrm{M}$ sodium chloride, containing $2 \%$ Tween $20, \mathrm{pH} 7.15)$. The leaf grinder was washed with $\approx 20-30 \mathrm{ml}$ of distilled water between extractions. Sap was stored in 2-ml microcentrifuge tubes and at $-20^{\circ} \mathrm{C}$. Individual samples were thawed and robotically transferred using a Tecan Genesis 150 (Tecan U.S., Durham, NC) to 96 well deep-well plates, for compact storage and efficient transfer to immunoassay plates, and then stored at $-20^{\circ} \mathrm{C}$. Samples were transferred to immunoassay plates for biotin-avidin double antibody sandwich, enzyme-linked immunosorbent assay (ELISA). This assay was completed as described by Krell et al. (2004) except for the use of a microtiter 96 Plate Washer (Tecan U.S.), for seven cycles of rinsing and aspiration. After washing, each plate was pat dried on paper toweling.

Seed Assessments. The percentage of discolored or mottled seed, seed weight, and relative amount of virus antigen in a sample were determined from a single random sample of 100 seeds harvested from each experimental unit. Individual seeds were counted as mottled if any discoloration was observed. Yield was determined by harvesting the center two (2002) or six rows (2003 and 2004) and recording the $13 \%$ moisture-corrected weight. Relative levels of virus antigen in seed were determined as described previously (Krell et al. 2005, Hill et al. 2007). Because SMV can be synergistic with BPMV (Ross 1968, Quiniones et al. 1971, Anjos et al. 1992), and because its symptoms are identical to those of BPMV, the relative antigen level of SMV also was determined. In this analysis a value of 1.0 or less indicates virus antigen was not detected. 

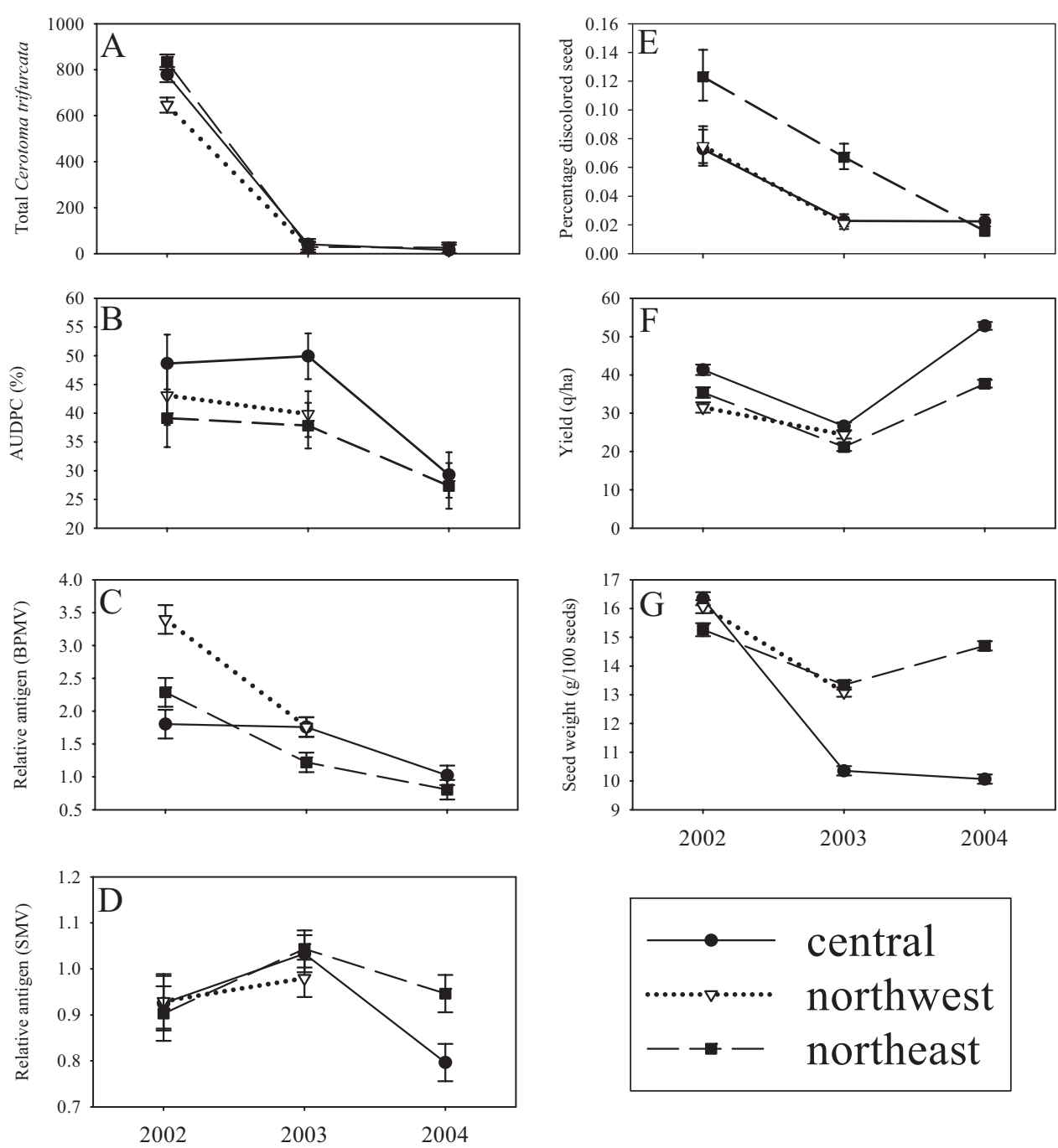

Fig. 1. Location by year interactions, mean \pm margin of error $(95 \% \mathrm{CI})$, for estimated total seasonal abundance of $C$. trifurcata (A), AUDPC of BPMV (B), relative amount of BPMV antigen in seed (C), relative amount of SMV antigen in seed (D), percentage discolored soybean seeds $(\mathrm{E})$, yield $(\mathrm{F})$, and 100-seed weight $(\mathrm{G})$ in experiments to reduce $C$. trifurcata abundance and BPMV incidence in 2002, 2003, and 2004 in soybean in Iowa.

Data Analysis. Data were analyzed using a mixed model analysis of variance (ANOVA), PROC MIXED (SAS Institute 2006), with blocks within locations declared as a random source of variance for mean comparisons for estimated total C. trifurcata abundance, pathogen incidence, and yield data. Data were combined where there was no significant interaction of treatment by location. For comparisons of treatment effects, data were analyzed separately by year. For comparisons of temporal C. trifurcata abundance between treatments, overall effects of treatment, date, and treatment by date were determined using a repeated measures analysis. The repeated subject (treatment by block) was modeled using a spatial power (using sampling date as the source of repeated variability) type of covariance structure and block was declared as a random source of variation. For repeated measures analysis, each year and location were treated separately because of differing correlations of covariance structures for the date effect using PROC MIXED (SAS Institute 2006). Treatment comparisons were analyzed further by date via Dunnett's test for differences with an untreated control to derive the mean significant difference with the control by using PROC MIXED (SAS Institute 2006). Denominator degrees of freedom for repeated measures were calculated using the Satterthwaite method. Count data were transformed by the square root of $(y+0.375)$ to stabilize the variance if indicated as necessary by residual plot examination (Kuel 2000).

Disease incidence was calculated using a generalized linear mixed model, PROC GLIMIXED (SAS Institute 2006), to derive the area under the disease progress curve (AUDPC) by using the trapezoidal 
Table 2. Total counts (mean $\pm \mathrm{SE}$ ) of teneral adult $C$. trifurcata from insecticidal treatments applied to affect the incidence of BPMV

\begin{tabular}{|c|c|c|c|c|c|}
\hline \multirow[b]{2}{*}{ Treatment $^{c}$} & \multicolumn{3}{|c|}{$2002^{a, b}$} & \multirow{2}{*}{$\begin{array}{c}2003 \\
\begin{array}{c}\text { Combined } \\
\text { locations }\end{array}\end{array}$} & \multirow{2}{*}{$\begin{array}{c}2004 \\
\begin{array}{c}\text { Combined } \\
\text { locations }\end{array}\end{array}$} \\
\hline & Central & Northeast & Northwest & & \\
\hline Clothianidin & $7.04 \pm 0.55$ & $4.86 \pm 0.55 b$ & $10.32 \pm 0.55$ & N.A. & N.A. \\
\hline Thiamethoxam & $7.45 \pm 0.55$ & $5.51 \pm 0.55 \mathrm{ab}$ & $10.39 \pm 0.55$ & $1.17 \pm 0.16 \mathrm{de}$ & $1.31 \pm 0.19 b$ \\
\hline Thiamethoxam $+\lambda$-cyhalothrin $\left(\mathrm{F}_{0}\right)^{c}$ & N.A. & N.A. & N.A. & $1.25 \pm 0.16 \mathrm{de}$ & $1.26 \pm 0.19 \mathrm{~b}$ \\
\hline Thiamethoxam $+\lambda$-cyhalothrin $\left(\mathrm{F}_{1}\right)$ & $7.05 \pm 0.55$ & $4.91 \pm 0.55 b$ & $9.27 \pm 0.55$ & $1.00 \pm 0.16 \mathrm{e}$ & $1.62 \pm 0.19 \mathrm{ab}$ \\
\hline$\lambda$-Cyhalothrin $\left(\mathrm{F}_{0}\right)$ & $7.70 \pm 0.55$ & $6.84 \pm 0.55 \mathrm{ab}$ & $11.58 \pm 0.55$ & $2.03 \pm 0.16 b$ & $1.78 \pm 0.19 \mathrm{ab}$ \\
\hline$\lambda$-Cyhalothrin $\left(\mathrm{F}_{1}\right)$ & $7.13 \pm 0.55$ & $5.00 \pm 0.55 \mathrm{ab}$ & $9.88 \pm 0.55$ & $2.07 \pm 0.16 \mathrm{~b}$ & $1.98 \pm 0.19 \mathrm{a}$ \\
\hline$\lambda$-Cyhalothrin $\left(\mathrm{F}_{0}+\mathrm{F}_{1}\right)$ & $7.21 \pm 0.55$ & $6.39 \pm 0.55 \mathrm{ab}$ & $9.20 \pm 0.55$ & $1.53 \pm 0.16 \mathrm{bcd}$ & $1.75 \pm 0.19 \mathrm{ab}$ \\
\hline Esfenvalerate $\left(\mathrm{F}_{0}+\mathrm{F}_{1}\right)$ & N.A. & N.A. & N.A. & $1.36 \pm 0.16 \mathrm{cde}$ & $1.55 \pm 0.19 \mathrm{ab}$ \\
\hline Untreated control & $6.62 \pm 0.55$ & $7.54 \pm 0.55 \mathrm{a}$ & $10.57 \pm 0.55$ & $2.87 \pm 0.16 \mathrm{a}$ & $2.08 \pm 0.19 \mathrm{a}$ \\
\hline
\end{tabular}

\section{N.A., not applicable.}

${ }^{a}$ Analysis of effects subdivided by year (2002-2003) and location (central, northeast, and northwest Iowa). Data for locations were combined where the interaction of location by treatment was not statistically significant $(P<0.05)$. Means (LS-means) and standard errors were calculated based on PROC MIXED (SAS Institute 2006).

${ }^{b}$ Means followed by the same letter, within locations, are not statistically different $(P<0.05)$. No letters indicate no statistically significant differences $(P<0.05)$. Means transformed by $\operatorname{sqrt}(y+0.375)$ (Kuel 2000).

${ }^{c}$ Symbols in parentheses indicates the target population $\left(\mathrm{F}_{0}\right.$ or $\left.\mathrm{F}_{1}\right)$ for the foliar application of $\lambda$-cyhalothrin and esfenvalerate.

method (based on the average percentage of ELISApositive leaflets per treatment as a function of day of year), and results were compared by ANOVA, PROC MIXED (SAS Institute 2006). Counts of discolored seed were analyzed using PROC GLIMIXED (SAS Institute 2006). Estimates are expressed as means \pm SE unless otherwise indicated. Times are in day of year unless otherwise stated. Overall $F$ values are notated as $F_{\text {ndf, ddf }}$ and $t$ values as $t_{\text {ddf }}$. The $\alpha$ level for statistical significance for all analyses was set at 0.05 .

\section{Results}

Interactions of Year by Location. Overall there was a significant location by year interaction for all response variables measured in this study (Fig. 1A-G). Although there was a marked decrease in total vector abundance (Fig. 1A), the AUDPC (=average total BPMV incidence as a function of day of year) for BPMV remained the same between years 2002 and 2003 (Fig. 1B) for all locations. This interaction followed a similar pattern within locations and across years in relative amounts of BPMV antigen in seed at the central and northeast locations (Fig. 1C). A low incidence of SMV antigen was detected in seed in 2003 (Fig. 1D). Seed coat color improved from 2002 to 2004 (Fig. 1E); however, yield and seed weight showed no clear trend in their location by year interaction (Fig. $1 \mathrm{~F}$ and $\mathrm{G})$.

Vector Control. Because year had a stronger influence on total $C$. trifurcata abundance than location (year: $F_{2,322}=4,217.46 ; P<0.0001$; location: $F_{2,14}=$ 40.92; $P<0.0001$ ) (Fig. 1A) and there were changes between years (e.g., insecticide application rates), estimates of total beetle abundance were analyzed by year. Overall the estimated total beetle populations (based on pooled averages from all study locations; pooled from in-row and sweep net samples) declined significantly $754.39 \pm 10.36,31.65 \pm 7.51$, and $3.45 \pm$ 9.29 beetles $\left(F_{2,354}=2,095.14 ; P<0.0001\right)$ from 2002 to 2004 , respectively (Fig. 1A). Of these adults, $\approx 8,11$, and $14 \%$ of C. trifurcata from 2002 to 2004 , respectively, were determined to be teneral (i.e., unsclerotized).

Assuming decreased mobility during C. trifurcata's teneral period (Chapman 1998), they may be more likely to have emerged from within plots than fully sclerotized adults. Therefore, the total seasonal abundance of teneral adults may indicate relative emergence from within an experimental unit and the impact of treatment. Based on relative counts of teneral beetles, seed treatment or seed treatment plus a foliar insecticide significantly reduced the total estimated emergence at the northeast location in 2002 (Table 2). In 2003, all locations had significantly reduced emergence relative to an untreated control with a seed treatment plus an $\mathrm{F}_{1}$-targeted insecticide having the greatest reduction (Table 2). In 2004 only those experimental units that incorporated a seed-applied insecticide had a significantly lower emergence relative to an untreated control (Table 2).

In 2002, no insecticide applications had a significant effect on estimated total C. trifurcata abundance at the central and northeast locations (Table 3). However, any $F_{1}$-targeted insecticide had significantly fewer beetles than an untreated control at the northwest location (Table 3). At the northwest location the $\mathrm{F}_{0^{-}}+$ $\mathrm{F}_{1}$-targeted insecticide program resulted in $388.69 \pm$ 47.8 fewer beetles than an $\mathrm{F}_{0}$-targeted insecticide alone regardless of the insecticide applied $\left(t_{54}=8.13\right.$, $P<0.0001)$.

In 2003, the $\mathrm{F}_{0}$-targeted insecticide treatments alone generally had fewer total beetles than an untreated control (Table 3). Based on a contrast comparison of the $\mathrm{F}_{0}$-targeted with the $\mathrm{F}_{1}$-targeted treatments, the $\mathrm{F}_{1}$-targeted treatments had slightly higher total beetle abundance at the central location, with $\mathrm{F}_{0^{-}}+\mathrm{F}_{1}$-targeted insecticide program having $11.98 \pm$ 2.98 more total C. trifurcata relative to a single $\mathrm{F}_{0^{-}}$ targeted insecticide regardless of the insecticide applied $\left(t_{147}=4.02, P<0.0001\right)$ (see Table 1 for reference to population targets used in this and subsequent 
Table 3. Total counts (mean $\pm \mathrm{SE}$ ) of adult $C$. trifurcata from insecticidal treatments applied to affect the incidence of BPMV

\begin{tabular}{|c|c|c|c|c|c|c|c|}
\hline \multirow[b]{2}{*}{ Treatment $^{c}$} & \multicolumn{3}{|c|}{$2002^{a, b}$} & \multicolumn{3}{|c|}{2003} & \multirow{2}{*}{$\begin{array}{c}2004 \\
\begin{array}{l}\text { Combined } \\
\text { locations }\end{array}\end{array}$} \\
\hline & Central & Northeast & Northwest & Central & Northeast & Northwest & \\
\hline Clothianidin & $799.50 \pm 67.27$ & $687.75 \pm 67.27$ & $726.50 \pm 67.27 \mathrm{bc}$ & N.A. & N.A. & N.A. & N.A. \\
\hline Thiamethoxam & $46.67 \pm 67.27$ & $808.00 \pm 67.27$ & $865.00 \pm 67.27 \mathrm{ab}$ & $29.88 \pm 4.86 \mathrm{~b}$ & $19.25 \pm 4.86 \mathrm{c}$ & $18.63 \pm 4.86 \mathrm{~b}$ & $17.88 \pm 2.87 \mathrm{bc}$ \\
\hline $\begin{array}{l}\text { Thiamethoxam }+ \\
\lambda \text {-cyhalothrin }\left(\mathrm{F}_{0}\right)^{c}\end{array}$ & N.A. & N.A. & N.A. & $35.13 \pm 4.86 \mathrm{ab}$ & $16.63 \pm 4.86 \mathrm{c}$ & $24.00 \pm 4.86 \mathrm{ab}$ & $16.69 \pm 2.87 \mathrm{c}$ \\
\hline $\begin{array}{l}\text { Thiamethoxam }+ \\
\lambda \text {-Cyhalothrin }\left(\mathrm{F}_{1}\right)\end{array}$ & $800.75 \pm 67.27$ & $750.75 \pm 67.27$ & $444.50 \pm 67.27 \mathrm{~cd}$ & $46.88 \pm 4.86 \mathrm{ab}$ & $18.00 \pm 4.86 \mathrm{c}$ & $22.13 \pm 4.86 \mathrm{ab}$ & $21.63 \pm 2.87 \mathrm{abc}$ \\
\hline$\lambda$-Cyhalothrin $\left(\mathrm{F}_{0}\right)$ & $723.50 \pm 67.27$ & $986.50 \pm 67.27$ & $867.00 \pm 67.27 \mathrm{ab}$ & $35.75 \pm 4.86 \mathrm{ab}$ & $33.50 \pm 4.86 \mathrm{bc}$ & $26.63 \pm 4.86 \mathrm{ab}$ & $23.00 \pm 2.87 \mathrm{abc}$ \\
\hline$\lambda$-Cyhalothrin $\left(\mathrm{F}_{1}\right)$ & $802.00 \pm 67.27$ & $785.75 \pm 67.27$ & $470.25 \pm 67.27 \mathrm{~cd}$ & $47.13 \pm 4.86 \mathrm{ab}$ & $45.00 \pm 4.86 \mathrm{ab}$ & $39.00 \pm 4.86 \mathrm{a}$ & $25.50 \pm 2.87 \mathrm{ab}$ \\
\hline$\lambda$-Cyhalothrin $\left(\mathrm{F}_{0}+\mathrm{F}_{1}\right)$ & $782.50 \pm 67.27$ & $824.25 \pm 67.27$ & $330.75 \pm 67.27 \mathrm{~d}$ & $44.00 \pm 4.86 \mathrm{ab}$ & $28.13 \pm 4.86 \mathrm{bc}$ & $29.13 \pm 4.86 \mathrm{ab}$ & $24.25 \pm 2.87 \mathrm{abc}$ \\
\hline Esfenvalerate $\left(\mathrm{F}_{0}+\mathrm{F}_{1}\right)$ & N.A. & N.A. & N.A. & $47.50 \pm 4.86 \mathrm{ab}$ & $30.88 \pm 4.86 \mathrm{bc}$ & $30.38 \pm 4.86 \mathrm{ab}$ & $21.63 \pm 2.87 \mathrm{abc}$ \\
\hline Untreated control & $789.00 \pm 67.27$ & $986.75 \pm 67.27$ & $813.50 \pm 67.27 \mathrm{ab}$ & $52.63 \pm 4.86 \mathrm{a}$ & $53.63 \pm 4.86 \mathrm{a}$ & $31.38 \pm 4.86 \mathrm{ab}$ & $26.69 \pm 4.86 \mathrm{a}$ \\
\hline
\end{tabular}

N.A., not applicable.

${ }^{a}$ Analysis of effects subdivided by year (2002-2003) and location (central, northeast, and northwest Iowa). Data for locations were combined where the interaction of location by treatment was not statistically significant $(P<0.05)$. Means (LS-means) and standard errors were calculated based on PROC MIXED (SAS Institute 2006).

${ }^{b}$ Means followed by the same letter, within locations, are not statistically different $(P<0.05)$. No letters indicate no statistically significant differences $(P<0.05)$.

${ }^{c}$ Symbols in parentheses indicate the target population $\left(F_{0}\right.$ or $\left.F_{1}\right)$ for the foliar application of $\lambda$-cyhalothrin and esfenvalerate.

contrasts). However, this contrast comparison was not significant for either northeast $\left(t_{147}=0.21, P<\right.$ $0.8310)$, or northwest $\left(t_{147}=1.38, P<0.1685\right)$ locations.

The results for 2004 were similar to $2003 ; \mathrm{F}_{0}$-targeted insecticide treatments had fewer total beetles (Table 3). This was particularly true for treatments that included seed-applied insecticides.

Temporal Effects. Significant changes were measured in the temporal abundance of bean leaf beetles in all years (Tables 4 and 5). Overall treatment effects were statistically significant at northeast and northwest locations in 2002, all locations in 2003, and the northeast location in 2004 for VE-V4 soybean stages (in situ counts; Table 4). For V5-R7 soybean stages, overall treatment effects were statistically significant at the northeast and northwest locations in 2002 and 2003 (sweep-net counts; Table 5).

Overall, a temporal analysis by sample date indicated that some insecticidal treatments significantly

Table 4. Overall tests of significance for temporal and treatment effects on adult $C$. trifurcata abundance (in situ counts), in VE-V4-stage soybean, for the management of BPMV in Iowa

\begin{tabular}{|c|c|c|c|c|c|c|}
\hline Yr & Location & $\begin{array}{l}\text { Sample date } \\
\text { range }^{a}\end{array}$ & Effect $^{b}$ & $\mathrm{ndf}, \mathrm{ddf}^{c}$ & $F^{d}$ & $P$ \\
\hline \multirow[t]{9}{*}{2002} & \multirow[t]{3}{*}{ Central } & \multirow[t]{3}{*}{$132-160$} & Trt & $6,30.5$ & 1.59 & 0.1837 \\
\hline & & & Time & $4,74.7$ & 111.02 & $<0.0001$ \\
\hline & & & Trt $\times$ time & $24,74.7$ & 2.07 & 0.0091 \\
\hline & \multirow[t]{3}{*}{ Northeast } & \multirow[t]{3}{*}{$141-164$} & Trt & 6,81 & 11.03 & $<0.0001$ \\
\hline & & & Time & 3,81 & 109.09 & $<0.0001$ \\
\hline & & & Trt $\times$ time & 18,81 & 4.80 & $<0.0001$ \\
\hline & \multirow[t]{3}{*}{ Northwest } & \multirow[t]{3}{*}{ 139-162 } & Trt & $6,36.2$ & 19.44 & $<0.0001$ \\
\hline & & & Time & 3,63 & 76.33 & $<0.0001$ \\
\hline & & & Trt $\times$ time & 18,63 & 5.15 & $<0.0001$ \\
\hline \multirow[t]{9}{*}{2003} & \multirow[t]{3}{*}{ Central } & \multirow[t]{3}{*}{$155-161$} & Trt & 7,49 & 8.86 & $<0.0001$ \\
\hline & & & Time & 1,56 & 8.64 & 0.0048 \\
\hline & & & Trt $\times$ time & 7,56 & 1.66 & 0.1390 \\
\hline & \multirow[t]{3}{*}{ Northeast } & \multirow[t]{3}{*}{$149-161$} & Trt & $7,40.8$ & 7.14 & $<0.0001$ \\
\hline & & & Time & $2,92.1$ & 19.92 & $<0.0001$ \\
\hline & & & Trt $\times$ time & $14,92.1$ & 2.73 & 0.0021 \\
\hline & \multirow[t]{3}{*}{ Northwest } & \multirow[t]{3}{*}{$148-159$} & Trt & 7,70 & 13.02 & $<0.0001$ \\
\hline & & & Time & 2,127 & 3.96 & 0.0214 \\
\hline & & & Trt $\times$ time & 14,127 & 6.06 & $<0.0001$ \\
\hline \multirow[t]{6}{*}{2004} & \multirow[t]{3}{*}{ Central } & \multirow[t]{3}{*}{$131-158$} & Trt & $7,49.7$ & 0.70 & 0.6709 \\
\hline & & & Time & 4,135 & 4.26 & 0.0028 \\
\hline & & & Trt $\times$ time & 28,135 & 1.30 & 0.1637 \\
\hline & \multirow[t]{3}{*}{ Northeast } & \multirow[t]{3}{*}{$138-159$} & Trt & 7,114 & 5.64 & $<0.0001$ \\
\hline & & & Time & 3,186 & 3.96 & 0.0091 \\
\hline & & & Trt $\times$ time & 21,186 & 2.89 & $<0.0001$ \\
\hline
\end{tabular}

\footnotetext{
${ }^{a}$ Sample dates expressed as day of year.

${ }^{b}$ Effects are experimental treatment (Trt), day of year (time), and interaction (Trt $\times$ time).

${ }^{c}$ Degrees of freedom calculated using the Satterthwaite method.

${ }^{d}$ Data analyzed using a repeated measures analysis of variance with treatment by block as a repeated subject.
} 
Table 5. Overall tests of significance for temporal and treatment effects on adult $C$. trifurcata abundance (sweep-net counts), in V5-R7-stage soybean, for the management of BPMV in Iowa

\begin{tabular}{|c|c|c|c|c|c|c|}
\hline Yr & Location & $\begin{array}{l}\text { Sample date } \\
\text { range }^{a}\end{array}$ & Effect $^{b}$ & $\operatorname{ndf}, \mathrm{ddf}^{c}$ & $F^{d}$ & $P$ \\
\hline \multirow[t]{9}{*}{2002} & \multirow[t]{3}{*}{ Central } & \multirow[t]{3}{*}{$169-266$} & Trt & $6,75.9$ & 0.05 & 0.9994 \\
\hline & & & Time & 14,189 & 191.53 & $<0.0001$ \\
\hline & & & Trt $\times$ time & 84,189 & 1.06 & 0.3629 \\
\hline & \multirow[t]{3}{*}{ Northeast } & \multirow[t]{3}{*}{$171-270$} & Trt & 6,284 & 8.84 & $<0.0001$ \\
\hline & & & Time & 14,289 & 159.23 & $<0.0001$ \\
\hline & & & Trt $\times$ time & 84,289 & 1.44 & 0.0146 \\
\hline & \multirow[t]{3}{*}{ Northwest } & \multirow[t]{3}{*}{$168-267$} & Trt & 6,312 & 20.47 & $<0.0001$ \\
\hline & & & Time & 14,312 & 220.67 & $<0.0001$ \\
\hline & & & Trt $\times$ time & 84,312 & 3.01 & $<0.0001$ \\
\hline \multirow[t]{9}{*}{2003} & \multirow[t]{3}{*}{ Central } & \multirow[t]{3}{*}{$169-251$} & Trt & 7,195 & 2.02 & 0.0549 \\
\hline & & & Time & 12,410 & 204.22 & $<0.0001$ \\
\hline & & & Trt $\times$ time & 85,410 & 0.88 & 0.7670 \\
\hline & \multirow[t]{3}{*}{ Northeast } & \multirow[t]{3}{*}{$167-263$} & Trt & 7,217 & 12.48 & $<0.0001$ \\
\hline & & & Time & 13,442 & 113.76 & $<0.0001$ \\
\hline & & & Trt $\times$ time & 91,442 & 2.80 & $<0.0001$ \\
\hline & \multirow[t]{3}{*}{ Northwest } & \multirow[t]{3}{*}{$167-261$} & Trt & 7,254 & 3.36 & 0.0019 \\
\hline & & & Time & 13,387 & 220.67 & $<0.0001$ \\
\hline & & & Trt $\times$ time & 91,387 & 1.32 & 0.0386 \\
\hline \multirow[t]{6}{*}{2004} & \multirow[t]{3}{*}{ Central } & \multirow[t]{3}{*}{$165-246$} & Trt & 7,665 & 1.81 & 0.0816 \\
\hline & & & Time & 11,665 & 86.31 & $<0.0001$ \\
\hline & & & Trt $\times$ time & 77,665 & 0.97 & 0.5597 \\
\hline & \multirow[t]{3}{*}{ Northeast } & \multirow[t]{3}{*}{$166-245$} & Trt & 7,169 & 1.64 & 0.1273 \\
\hline & & & Time & 10,277 & 117.37 & $<0.0001$ \\
\hline & & & Trt $\times$ time & 70,277 & 0.93 & 0.6301 \\
\hline
\end{tabular}

${ }^{a}$ Sample dates expressed as day of year.

${ }^{b}$ Effects are experimental treatment (Trt), day of year (time), and interaction (Trt $\times$ time).

${ }^{c}$ Degrees of freedom calculated using the Satterthwaite method.

${ }^{d}$ Data analyzed using a repeated measures analysis of variance with treatment by block as a repeated subject.

reduced beetle abundance during times of increasing beetle abundance for some locations (Figs. 2-4). By in situ, early-season counts there were no significant treatment effects at the central location in 2002 according to the overall analysis (Table 4; Fig. 2A), $\mathrm{F}_{0}$-targeted insecticides significantly reduced $\mathrm{F}_{0}$ abundance relative to the untreated control at northeast (day 150: $F_{6,18}=3.31 ; P=0.0224$; day $157: F_{6,18}=$ 12.65; $P<0.0001$ ) (Fig. $2 \mathrm{~B}$ ) and northwest (day 148: $F_{6,18}=20.19 ; P<0.0001$; day $155: F_{6,18}=17.27 ; P<$ 0.0001 ) (Fig. 2C) locations. In 2003, central (day 155: $F_{7,49}=2.90 ; P=0.0128 ;$ day $161: F_{7,19}=7.31 ; P<$ 0.0001 ) (Fig. 3A), northeast (day 161: $F_{7,49}=11.80$; $P<0.0001$; day 167: $\left.F_{7,49}=4.80 ; P=0.0004\right)$ (Fig. 3B) and northwest (day 155: $F_{7,49}=9.17 ; P<0.0001$; day 167: $F_{7,49}=3.78 ; P=0.0024$ ) (Fig. 3C) locations had significantly reduced $\mathrm{F}_{0}$ populations via $\mathrm{F}_{0}$-targeted insecticides (Table 4). In 2004, there were no significant treatment effects at the central location (Table 4; Fig. 4A) and only $2 \mathrm{~d}$ of insecticidal reduction of $C$. trifurcata populations at the northeast location (day 155: $F_{7,49}=7.36 ; P<0.0001$; day $160: F_{7,49}=3.04 ; P=$ 0.0097) (Table 4; Fig. 4B).

For all years, according to mid- to late-season 20sweep counts, the response of $F_{1}$ and $F_{2}$ populations to insecticides generally was more variable than that of $\mathrm{F}_{0}$ populations. Although there were no significant overall treatment effects for the central location in 2002 (Table 5; Fig. 2A), $\mathrm{F}_{1}$-targeted applications reduced C. trifurcata abundance below that of a control at northeast (day 190: $F_{7,49}=21.81 ; P<0.0001$; day 197: $F_{6,18}=4.18 ; P=0.0084$; day $231: F_{6,18}=7.79 ; P=$
0.0003; day 242: $\left.F_{6,18}=8.08 ; P=0.0002\right)($ Fig. $2 \mathrm{~B})$ and northwest locations (day 192: $F_{6,18}=3.23 ; P=0.0246$; day $197: F_{6,18}=4.82 ; P=0.0042$; day $211: F_{6,18}=4.14$; $P=0.0088$; day $233: F_{6,18}=4.81 ; P=0.0043$; day 239 : $F_{6,18}=8.15 ; P=0.0002 ;$ day $246: F_{6,18}=12.50 ; P<$ 0.0001 ; day $253: F_{6,18}=7.03 ; P=0.0006$ ) (Fig. $2 \mathrm{C}$ ) in 2002; and in 2003 at the central (day 204: $F_{7,49}=8.98$; $P<0.0001$ ) (Fig. 3A), northeast (day 202: $F_{7,49}=7.52$; $P<0.0001$; day 209: $F_{7,49}=3.14 ; P=0.0081$; day 225 : $F_{7,49}=7.54 ; P<0.0001 ;$ day $254: F_{7,49}=8.37 ; P<$ 0.0001 ) (Fig. 3B), and northwest locations (day 203: $F_{7.49}=3.98 ; P=0.0016$ ) (Fig. 3C). The central location was not affected by insecticides in 2004 (Table 4; Fig. $4 \mathrm{~A}$ ), and only $1 \mathrm{~d}$ at the northeast location had a significant reduction in C. trifurcata abundance via $\mathrm{F}_{1}$-targeted applications (day 195: $F_{7,49}=2.71 ; P=$ 0.0187) (Fig. 4B)

In 2002, all locations had late-season populations $\left(\mathrm{F}_{1}\right.$ and $\left.\mathrm{F}_{2}\right)$ of $C$. trifurcata that foreshadowed at least a measurable yield loss (Lam et al. 2000) (Fig. 5A) whereas populations at all locations in 2003 (Fig. 5B) or 2004 (Fig. 5C) were much lower. Additionally, in 2002 , distinct $F_{1}$ and $F_{2}$ populations could only be detected at the northwest location (Fig. 5A) where the onset of $\mathrm{F}_{2}$ populations were delayed $\approx 15 \mathrm{~d}$ by the application of an $\mathrm{F}_{1}$-targeted insecticide at northwest (data not shown).

An $\mathrm{F}_{0^{-}}+$an $\mathrm{F}_{1}$-targeted insecticide program reduced $C$. trifurcata abundance through calendar dates $168-267$ by $1.50 \pm 0.16\left(t_{312}=9.33, P<0.0001\right)$ beetles via the addition of the $\mathrm{F}_{1}$-targeted insecticide in 2002 at northwest relative to an $\mathrm{F}_{0}$-targeted insecticide 

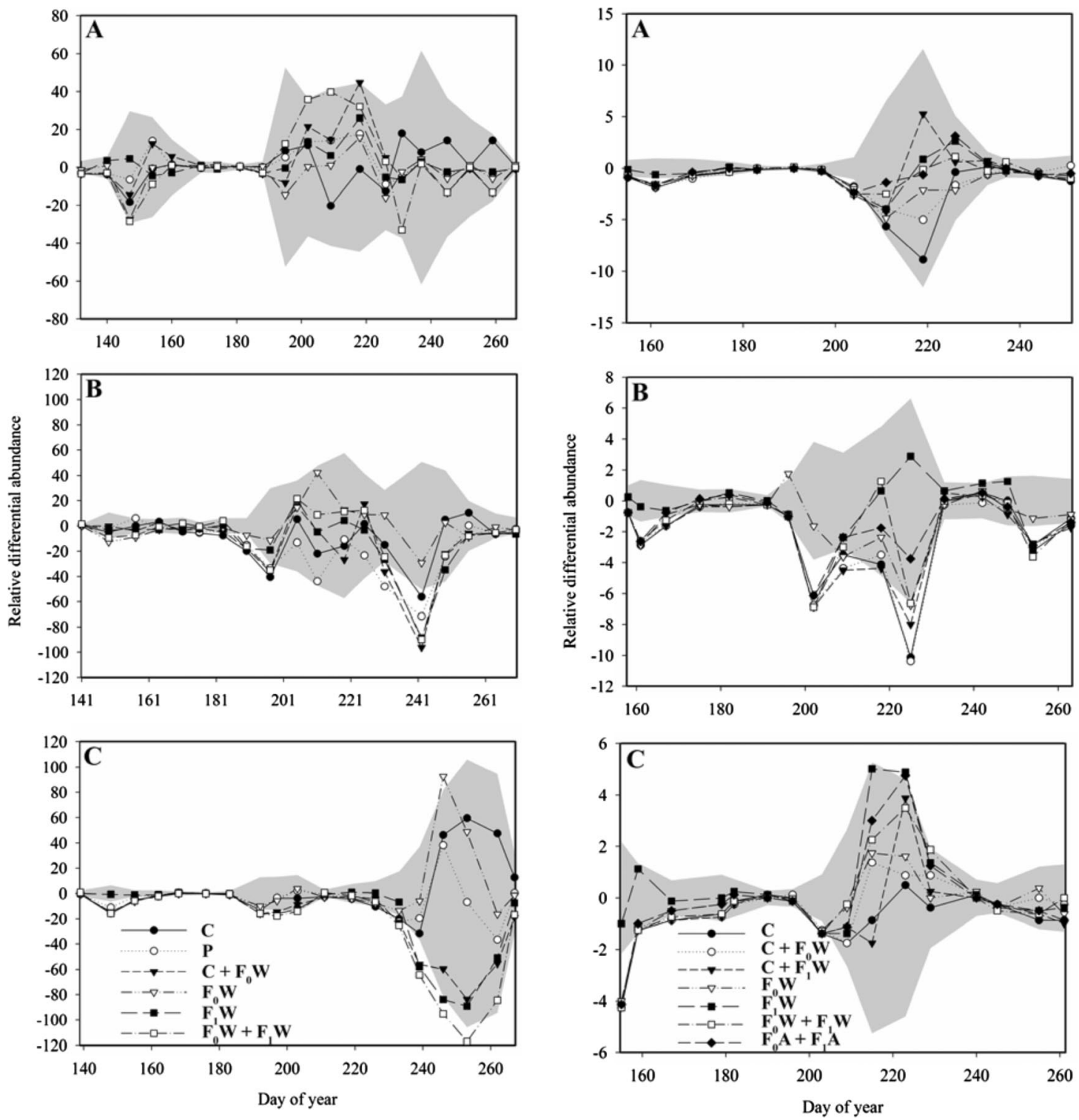

Fig. 2. Difference between means of $C$. trifurcata counts in central (A), northeast (B), and northwest (C) Iowa in 2002 (relative abundance of the untreated control minus treatment plots). Estimates inside the gray area are not different from the control according to the minimum significant difference of Dunnett's $t$-test. Treatments are seed-applied neonicotinoids ( $\mathrm{C}$ and $\mathrm{P}$ ) or a pyrethroid (W) applied to target the onset of $\mathrm{F}_{0}$ or $\mathrm{F}_{0}$ and $\mathrm{F}_{1}$ C. trifurcata populations. Foliar application dates for central: $\mathrm{F}_{0} \mathrm{~W}$, day 138 (18 May) and $\mathrm{F}_{1} \mathrm{~W}$, day 184 (3 July); northeast: $\mathrm{F}_{0} \mathrm{~W}$, day 148 (28 May) and $\mathrm{F}_{1} \mathrm{~W}$, day 183 (2 July); and northwest: $\mathrm{F}_{0} \mathrm{~W}$, day 144 (24 May) and $F_{1} W$, day 189 (8 July).

alone at the northwest location. Additionally, as similarly reported for total beetle counts, $C$. trifurcata populations increased by $0.13 \pm 0.06\left(t_{195}=2.16, P=\right.$ $0.0318)$ through calendar dates $169-251$ at the central location in 2003 with the addition of the $F_{1}$-targeted

Fig. 3. Difference between means of C. trifurcata counts in central (A), northeast (B), and northwest (C) Iowa in 2003 (relative abundance of the untreated control minus treatment plots). Estimates inside the gray area are not different from the control according to the minimum significant difference of Dunnett's $t$-test. Treatments are seed-applied neonicotinoids (C) or a pyrethroid (W and A) applied to target the onset of $\mathrm{F}_{0}$ or $\mathrm{F}_{0}$ andF $\mathrm{F}_{1}$ C. trifurcata populations. Foliar application dates for central: $\mathrm{F}_{0} \mathrm{~W}$ or $\mathrm{F}_{0} \mathrm{~A}$, day 155 (4 June) and $F_{1} W$ or $F_{1} A$, day 195 (14 July); northeast: $F_{0} W$ or $\mathrm{F}_{0} \mathrm{~A}$, day 152 (1 June) and $\mathrm{F}_{1} \mathrm{~W}$ or $\mathrm{F}_{1} \mathrm{~A}$, day 194 (13 July); and northwest: $\mathrm{F}_{0} \mathrm{~W}$ or $\mathrm{F}_{0} \mathrm{~A}$, day 151 (31 May) and $\mathrm{F}_{1} \mathrm{~W}$ or $\mathrm{F}_{1} \mathrm{~A}$, day 196 (17 July).

insecticide, in $\mathrm{F}_{0^{-}}+\mathrm{F}_{1}$-targeted insecticide program, relative to an $\mathrm{F}_{0}$-targeted insecticide alone.

Virus Control. As with C. trifurcata abundance, BPMV incidence generally declined between 2002 and 2004; however, overall incidence in 2003 was sta- 


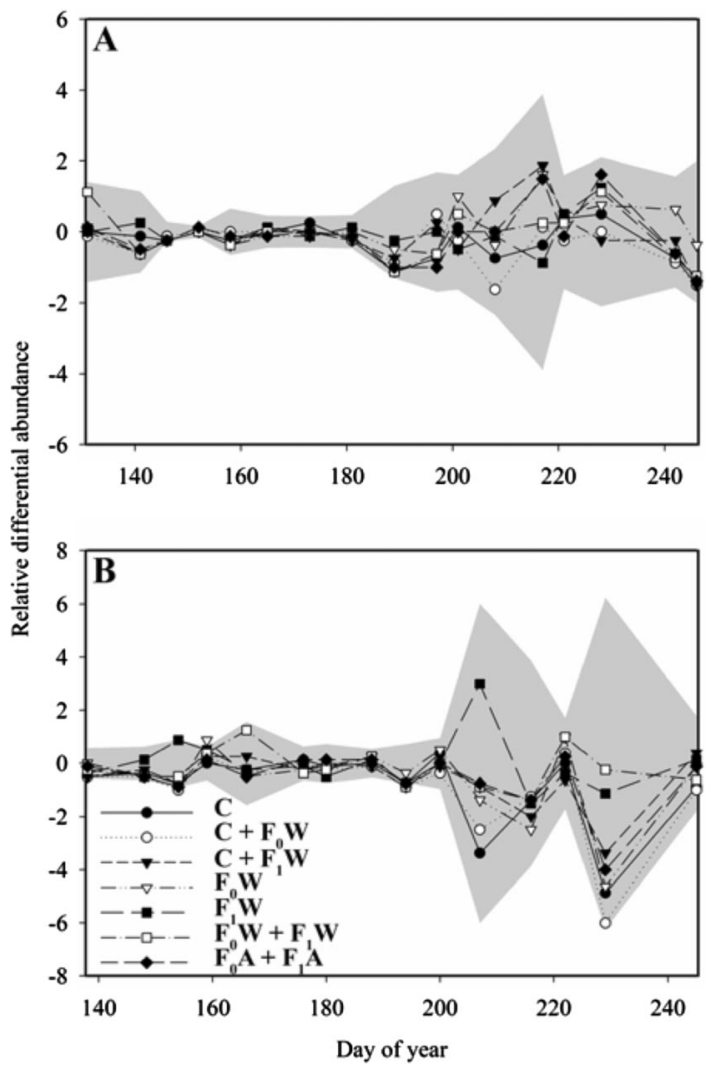

Fig. 4. Difference between means of C. trifurcata counts in central (A) and northeast (B) Iowa in 2004 (relative abundance of the untreated control minus treatment plots). Estimates inside the gray area are not different from the control according to the minimum significant difference of Dunnett's $t$-test. Treatments are seed-applied neonicotinoids (C) or a pyrethroid (W and $\mathrm{A}$ ) applied to target the onset of $\mathrm{F}_{0}$ or $\mathrm{F}_{0}$ and $\mathrm{F}_{1}$ C. trifurcata populations. Foliar application dates for central: $\mathrm{F}_{0} \mathrm{~W}$ or $\mathrm{F}_{0} \mathrm{~A}$, day 141 (20 May) and $\mathrm{F}_{1} \mathrm{~W}$ or $\mathrm{F}_{1} \mathrm{~A}$, day 183 (1 July) and northeast: $\mathrm{F}_{0} \mathrm{~W}$ or $\mathrm{F}_{0} \mathrm{~A}$, day 140 (19 May) and $F_{1} W$ or $F_{1} A$, day 190 (8 July).

tistically similar to 2002 (Fig. 1B), based on the AUDPC. In addition to this temporal trend, virus incidence was generally higher at the central location for each year. This trend agrees with the current understanding of BPMV prevalence in Iowa: it increases from north to south (Robertson and Nutter 2006). Additionally, even in years where total C. trifurcata abundance never exceeded 30 individuals (2004; Table 3), the AUDPC was never below the minimum damage boundary of $20 \%$ (Horn et al. 1973) reported for BPMV incidence (Fig. 1B).

Disease progress curves for BPMV were pooled by location based on a nonsignificant location by treatment interaction within each year (Fig. 6A-C). Although the incidence of BPMV at $2 \mathrm{wk}$ after planting was similar between 2002 and 2003, the onset of BPMV may have occurred earlier in 2002 (Fig. 6, A1 and B1). Bean pod mottle virus progress remained at or below $20 \%$ throughout most of 2004 (Fig. 6C1). In 2002, only
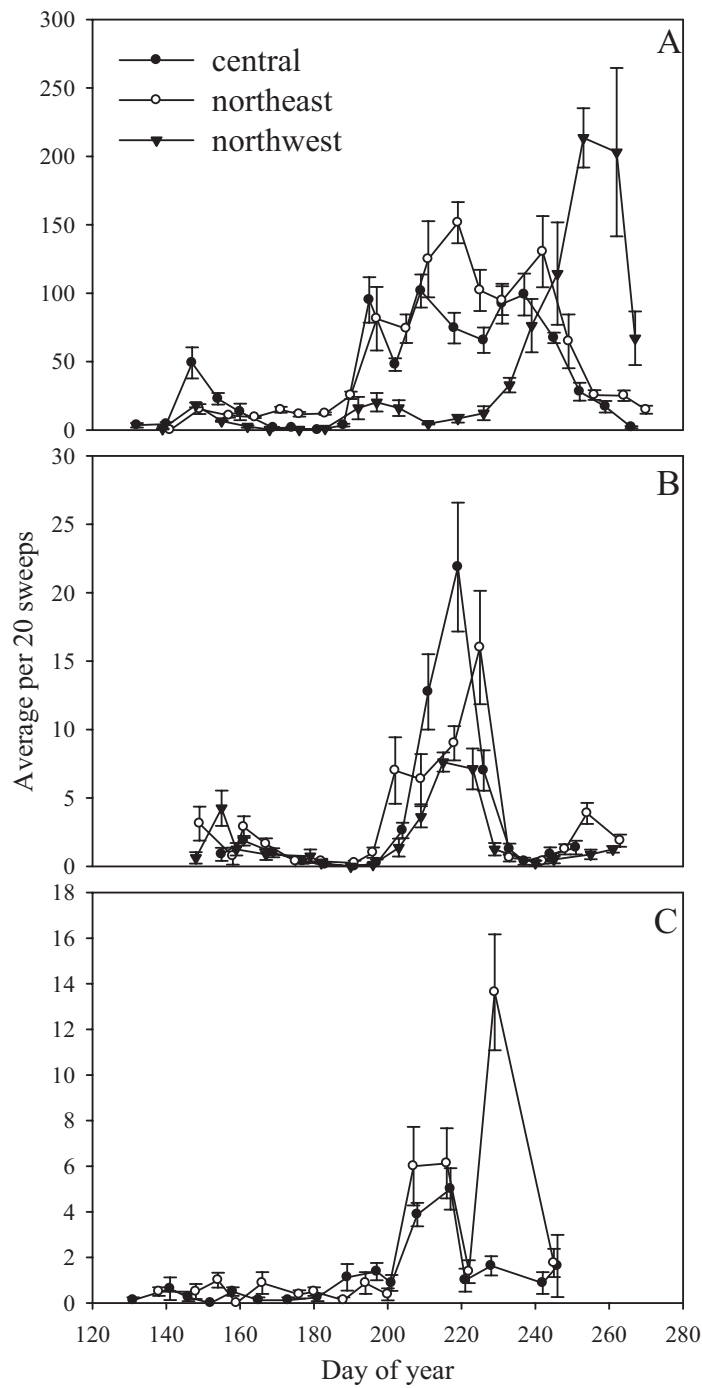

Fig. 5. Mean $\pm \mathrm{SE}$ (errors calculated by date) abundance of C. trifurcata in untreated plots at central, northeast, and northwest locations in Iowa, in 2002 (A), 2003 (B), and 2004 (C).

a seed-applied insecticide alone significantly reduced the AUDPC relative to an untreated control $\left(F_{6,54}=\right.$ 2.48; $P=0.0340$ ) (Fig. 6A2). In 2003, there were no significant pairwise treatment differences in the AUDPC compared with the untreated control (Fig. 6B2). However, the $\mathrm{F}_{0^{-}}+$an $\mathrm{F}_{1}$-targeted insecticide program increased the AUDPC by $11.98 \pm 2.98 \%$ $\left(t_{147}=4.02, P=0.0001\right)$ relative to the $\mathrm{F}_{0}$-targeted insecticide alone at the northwest location in 2003. However, this increase in incidence did not surpass that of the untreated control. There were no significant effects of treatment on AUDPC in 2004 (Fig. 6C).

Although the relative level of virus antigen in seed did not resolve pairwise treatment differences (Fig. $7 \mathrm{~A}-\mathrm{F})$, there were significant year and location effects (Fig. 1C). The overall treatment effects were only 

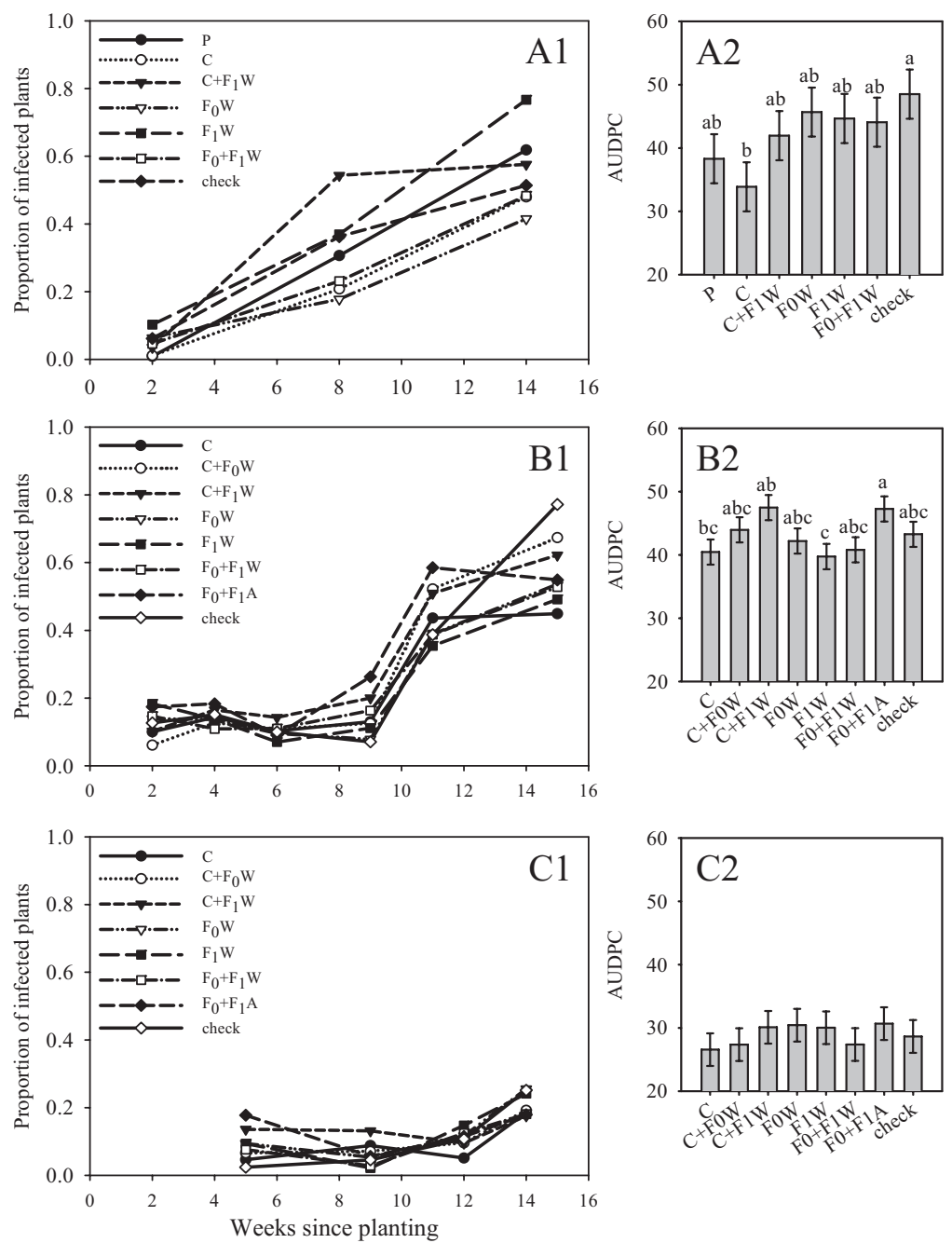

Fig. 6. Disease progress curves and AUDPC of BPMV in soybean from experiments to reduce C. trifurcata and BPMV in soybean in 2002 (A1 and A2), 2003 (B1 and B2), and 2004 (C1 and C2). Data combined from central, northeast, and northwest Iowa $(P>0.05$ for all location by treatment interactions within years). Treatments (2002): C, Cruiser; P, Poncho; $\mathrm{W}$, Warrior; $\mathrm{F}_{0}$, early-season population target; $\mathrm{F}_{1}$, mid-season population target; check, untreated control. Treatments (2003-2004): C, Cruiser; A, Asana; W, Warrior; $F_{0}$, early-season population target; $F_{1}$, mid-season population target; check, untreated control. AUDPC treatment means grouped by the same lowercase letter are not significantly different $(P<0.05)$. There was no significant location by treatment interaction $(P<0.05)$.

significant in 2002 at the central location $\left(F_{6,54}=3.83\right.$; $P=0.003$ ) (Fig. 7A) for which a thiamethoxam seed application alone resulted in a high relative amount of BPMV in seed. Additionally, when seed was assayed for SMV, only 2003 had detectable amounts of SMV (Fig. 1D); however, the average relative amount of antigen was not significantly $>1$ (i.e., its $95 \%$ confidence interval [CI] includes 1). Therefore, although SMV was detected, synergistic interactions between BPMV and SMV were not likely.

Agronomic Effects. Yield generally was highest in treatments with $\mathrm{F}_{0^{-}}+\mathrm{F}_{1}$-targeted insecticide applications (Figs. 8A-E); however, yields were only statistically significant in three out of the eight location by year combinations (note that some locations were combined based on nonsignificant location by year interactions). There were some significant treatment effect in $2003\left(F_{7.147}=4.94 ; P<0.0001\right)$ (Fig. 8B) and $2004\left(F_{7,98}=4.43 ; P=0.0003\right)$ (Fig. $8 \mathrm{E}$ ). Based on contrast comparisons an $\mathrm{F}_{0^{-}}+\mathrm{F}_{1^{-}}$-targeted insecticide program increased yield in 2003 at the central location by $1.42 \pm 0.54 \mathrm{q} \mathrm{ha}^{-1}\left(\approx 2.11 \mathrm{bu} \mathrm{acre}^{-1}\right) \quad\left(t_{147}=2.63\right.$, $P=0.0094)$, northeast by $1.67 \pm 0.54 \mathrm{q} \mathrm{ha}^{-1}(\approx 2.49 \mathrm{bu}$ acre $\left.^{-1}\right)\left(t_{147}=3.11, P=0.0023\right)$, and northwest by $1.55 \pm 0.54 \mathrm{qha}^{-1}\left(\approx 2.31 \mathrm{bu}\right.$ acre $\left.^{-1}\right)\left(t_{147}=2.89, P=\right.$ $0.0045)$ relative to an $\mathrm{F}_{0}$-targeted insecticide application alone. However, the same comparison in 2004 resulted in a $2.26 \pm 0.63 \mathrm{q} \mathrm{ha}^{-1}\left(\approx 3.36 \mathrm{bu} \mathrm{acre}^{-1}\right)$ $\left(t_{98}=3.61, P=0.0005\right)$ decrease in yield at the northeast location. 

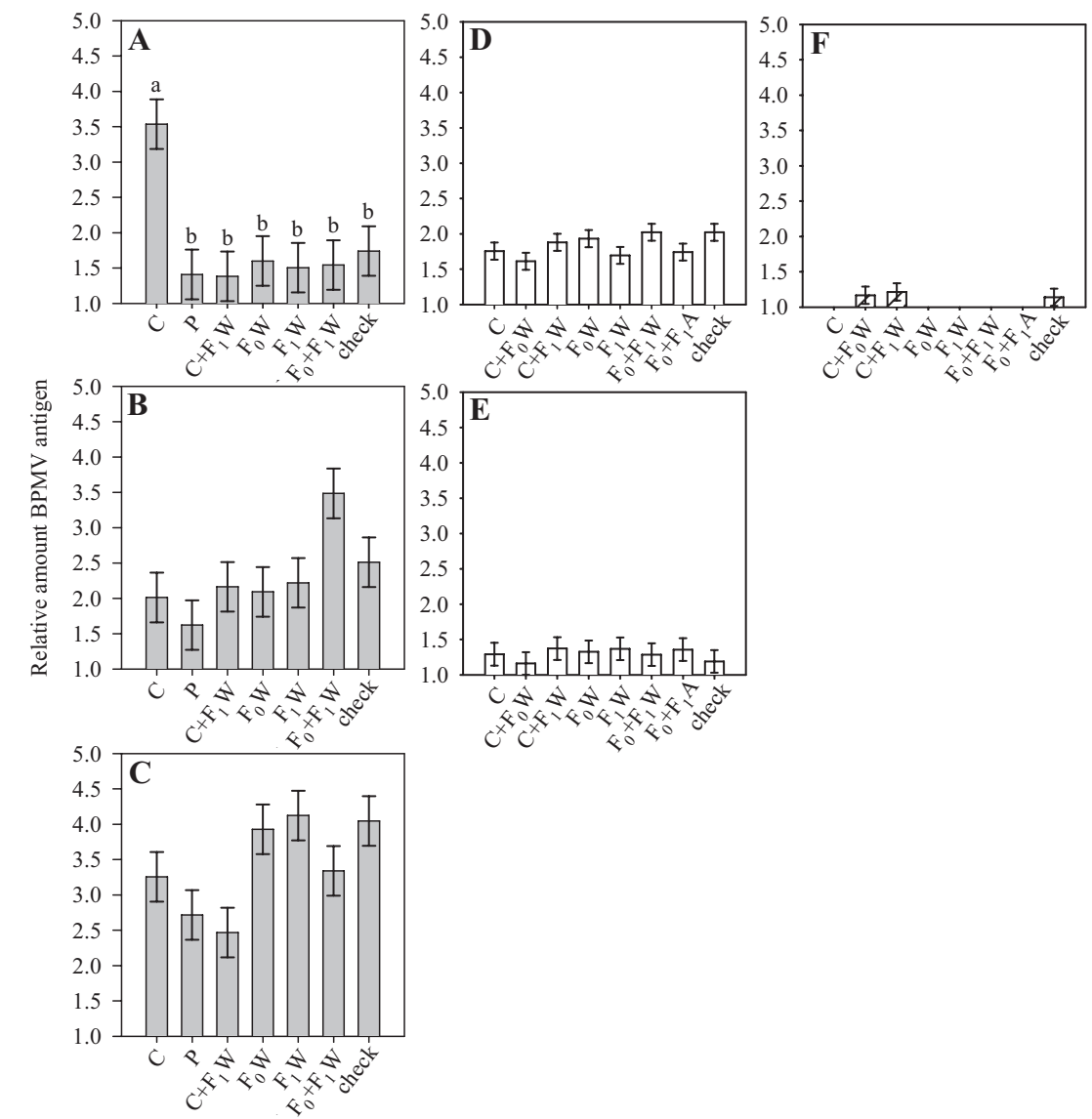

Fig. 7. Mean \pm SE relative BPMV antigen in soybean seeds from experiments to reduce C. trifurcata abundance and BPMV incidence in 2002 (gray bars), 2003 (white bars), and 2004 (hatched bars). Data from central (A), northeast (B), northwest $\left(\mathrm{C}\right.$ and $\mathrm{E}$ ), or central and northeast Iowa combined (D and F). Treatments (2002): C, Cruiser; P, Poncho; W, Warrior; $\mathrm{F}_{0}$, early-season population target; $\mathrm{F}_{1}$, mid-season population target; check, untreated control. Treatments (2003-2004): C, Cruiser; A, Asana; W, Warrior; $\mathrm{F}_{0}$, early-season population target; $\mathrm{F}_{1}$, mid-season population target; check, untreated control. Treatment means based on ELISA, with normalized hydrolysis times, of a pooled 100 seeds from each experimental unit and relative to an uninfected 100 -seed control. Values $>1.0$ define relative amount of antigen measured. Means grouped by the same lowercase letter are not significantly different $(P<0.05)$. Data grouped by location based on significant location by treatment interactions $(P<0.05)$.

Location had a significant effect on 100-seed weight for all years (2002: $F_{2,9}=30.30 ; P=0.0001 ; 2003$ : $F_{2,21}=241.54 ; P<0.0001 ; 2004: F_{1,14}=2822.04 ; P<$ $0.0001)$ as well as the interaction of location by treatment (Fig. 1G) for years $2002\left(F_{12,54}=3.27 ; P=\right.$ $0.0014)$ and $2003\left(F_{14,147}=4.37 ; P<0.0001\right)$. There were no significant pairwise treatment effects in 2002 (Fig. 9A and B). However, treatment had some significant effect on 100-seed weight for $2003\left(F_{7,147}=\right.$ $7.82 ; P<0.0001)$ (Fig. 9C-E) and $2004\left(F_{7,98}=3.71\right.$; $P=0.0013$ ) (Fig. 9F). In general the addition of an $\mathrm{F}_{1}$-targeted insecticide significantly reduced seed weight by $0.59 \pm 0.23,0.52 \pm 0.12$, and $0.22 \pm 0.10 \mathrm{~g}$ per 100-seeds from 2002 to 2004 , respectively, relative to a $\mathrm{F}_{0}$-targeted treatment $\left(t_{54}=2.62, P=0.0113\right.$ [ Fig. 9B:]; $t_{147}=4.53, P<0.0001$ [ Fig. $9 \mathrm{E}$ ] $; t_{147}=4.53, P<$ 0.0001 [Fig. 9F]). This relationship in reduced seed weight held though soybean varieties differed between 2002 and 2003-2004.
Treatment had some significant effect on seed-coat discoloration for $2002\left(F_{6,54}=9.40 ; P<0.0001\right)$ (Fig. $10 \mathrm{~A}-\mathrm{C})$ and $2003\left(F_{7,146}=2.48 ; P=0.0196\right)($ Fig. $10 \mathrm{D}$ and $\mathrm{E}$ ), with significant interactions of location by treatment for both years $\left(2002: F_{12.54}=2.82 ; P=\right.$ 0.0046; 2003: $\left.F_{14,146}=2.94 ; P=0.0006\right)$. However, there were no significant effects of treatment, location, or treatment by location for 2004 (Fig. 10F). Overall, the $\mathrm{F}_{1}$-targeted insecticide significantly improved seed color (Fig. 10B and C, and D). An $\mathrm{F}_{0^{-}}+$ $\mathrm{F}_{1}$-targeted insecticide strategy resulted in $\approx 5-10 \%$ fewer mottled seeds through the addition of a $\mathrm{F}_{1^{-}}$ targeted insecticide (2002, northwest: $t_{54}=4.74, P<$ $0.0001 ; 2003$, northeast: $t_{146}=3.73, P=0.0003$ ) based on a contrast comparison of $\mathrm{F}_{0}$ minus the $\mathrm{F}_{0^{-}}+\mathrm{F}_{1^{-}}$ targeted insecticide treatments. However, this improvement in seed color was less consistent if the $\mathrm{F}_{0}$-targeted insecticide was applied as a seed treatment in 2002 (Fig. 10B and C). In fact, an $\mathrm{F}_{1}$-targeted 

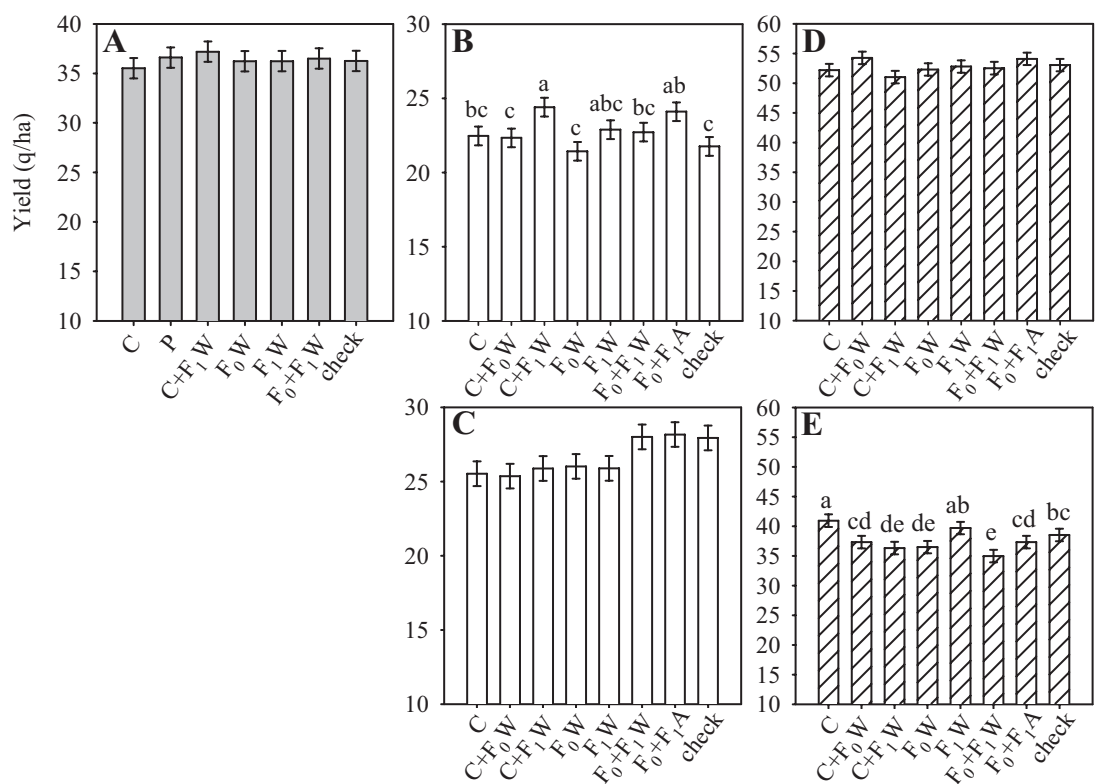

Fig. 8. Mean \pm SE yield in experiments to reduce C. trifurcata abundance and BPMV incidence in 2002 (gray bars), 2003 (white bars), and 2004 (hatched bars). Data from central, northeast, and northwest combined (A), northeast and northwest combined (B), central (C and D), and northeast (E) Iowa. Yields were standardized to 13\% moisture. Treatments (2002): $\mathrm{C}$, Cruiser; $\mathrm{P}$, Poncho; W, Warrior; $\mathrm{F}_{0}$, early-season population target; $\mathrm{F}_{1}$, mid-season population target; check, untreated control. Treatments (2003-2004): C, Cruiser; A, Asana; W, Warrior; $\mathbf{F}_{0}$, early-season population target; $\mathrm{F}_{1}$, mid-season population target; check, untreated control. Means grouped by the same lowercase letter are not significantly different $(P<$ $0.05)$. Data grouped by location based on significant location by treatment interactions $(P<0.05)$.

insecticide alone was often sufficient to protect seed color (Fig. 10B and C, and D).

\section{Discussion}

Seed-applied insecticide by itself significantly reduced the AUDPC of BPMV in an outbreak year, 2002, and the AUDPC was numerically lower than a control in 2003 and 2004. A foliar insecticide program targeting $\mathrm{F}_{0}+\mathrm{F}_{1}$ C. trifurcata numerically decreased the AUDPC, as similarly found by Krell et al. (2004), whereas the addition of a foliar insecticide application to a seed-applied insecticide may have increased BPMV incidence relative to a seed-applied insecticide alone (Fig. 6A-C). However, only in 2002 did any treatment have a significantly lower AUDPC relative to an untreated control. Furthermore, in 2002 all treatments had a numerically lower AUDPC than the untreated control. The onset of BPMV apparently occurred earlier in check plots in 2002 than in other years (Fig. 6A1, B1, and C1). Therefore, the effect of vector suppression and its corresponding impact on BPMV in soybean may have been most apparent in 2002. Under high bean leaf beetle pressure, our findings agree with Daniels (2004) and indicate that seed-applied insecticides targeting $\mathrm{F}_{0}$ C. trifurcata populations can reduce BPMV. However, further study is needed to understand how these treatments affect the temporal progression of BPMV.

Vector management costs for the $\mathrm{F}_{0^{-}}+\mathrm{F}_{1}$-targeted foliar insecticide program were approximately $\$ 30.27$ $\mathrm{ha}^{-1}\left(\$ 12.25 \mathrm{acre}^{-1}\right)$ for 2002 and $\$ 33.30 \mathrm{ha}^{-1}(\$ 13.48$ acre $^{-1}$ ) for 2003 and 2004. When a seed-treated insecticide was used in this program, management costs were $\$ 36.28 \mathrm{ha}^{-1}\left(\$ 14.68 \mathrm{acre}^{-1}\right)$ at the central and northwest location or $\$ 37.20 \mathrm{ha}^{-1}\left(\$ 15.06 \mathrm{acre}^{-1}\right)$ at the northeast location, assuming a 163,000 -seed bag and using the average crop value for soybean between 2002 and 2004 of $\$ 23.26 \mathrm{q}^{-1}\left(\$ 6.33 \mathrm{bu}^{-1}\right)$. Dividing the management costs $\left(\$ \mathrm{ha}^{-1}\right)$ by the market value $(\$$ $\mathrm{q}^{-1}$ ) of the crop the yield savings required to make a profit, or the gain threshold (Pedigo and Rice 2006), were determined. The gain thresholds were 1.30-1.43 $\mathrm{q} \mathrm{ha}{ }^{-1}$ (1.93-2.13 bu acre ${ }^{-1}$ ) for $\mathrm{F}_{0^{-}}+\mathrm{F}_{1}$-targeted foliar insecticides and 1.56-1.59 q ha $\mathrm{qa}^{-1}(2.32-2.38 \mathrm{bu}$ acre $^{-1}$ ) if a seed-treated insecticide is used as the $\mathrm{F}_{0}$-targeted insecticide. The greatest yield protection was recorded with the $\mathrm{F}_{0^{-}}+\mathrm{F}_{1}$-targeted insecticide strategy. Specifically, the gain threshold was exceeded by $\approx 1.1 \mathrm{q} \mathrm{ha}^{-1}\left(\approx 1.6 \mathrm{bu} \mathrm{acre}^{-1}\right)$ or $0.9 \mathrm{q} \mathrm{ha}^{-1}(\approx 1.3$ bu a $^{-1}$ ) if a seed-applied or foliar insecticide, respectively, was used as the $\mathrm{F}_{0}$-targeted insecticide in 2003 at the northeast and northwest locations. These gainthreshold calculations do not include penalties (e.g., yield reduction associated with management activities or discounted prices due to grain quality).

The results presented here support Krell et al. (2004) that $F_{0}$-targeted insecticides can suppress $F_{1}$ populations and that the success of an $\mathrm{F}_{1}$-targeted insecticide strongly depends on the seasonal dynamics of C. trifurcata. According to teneral cohort abundance, seed-applied insecticide is most efficient in 

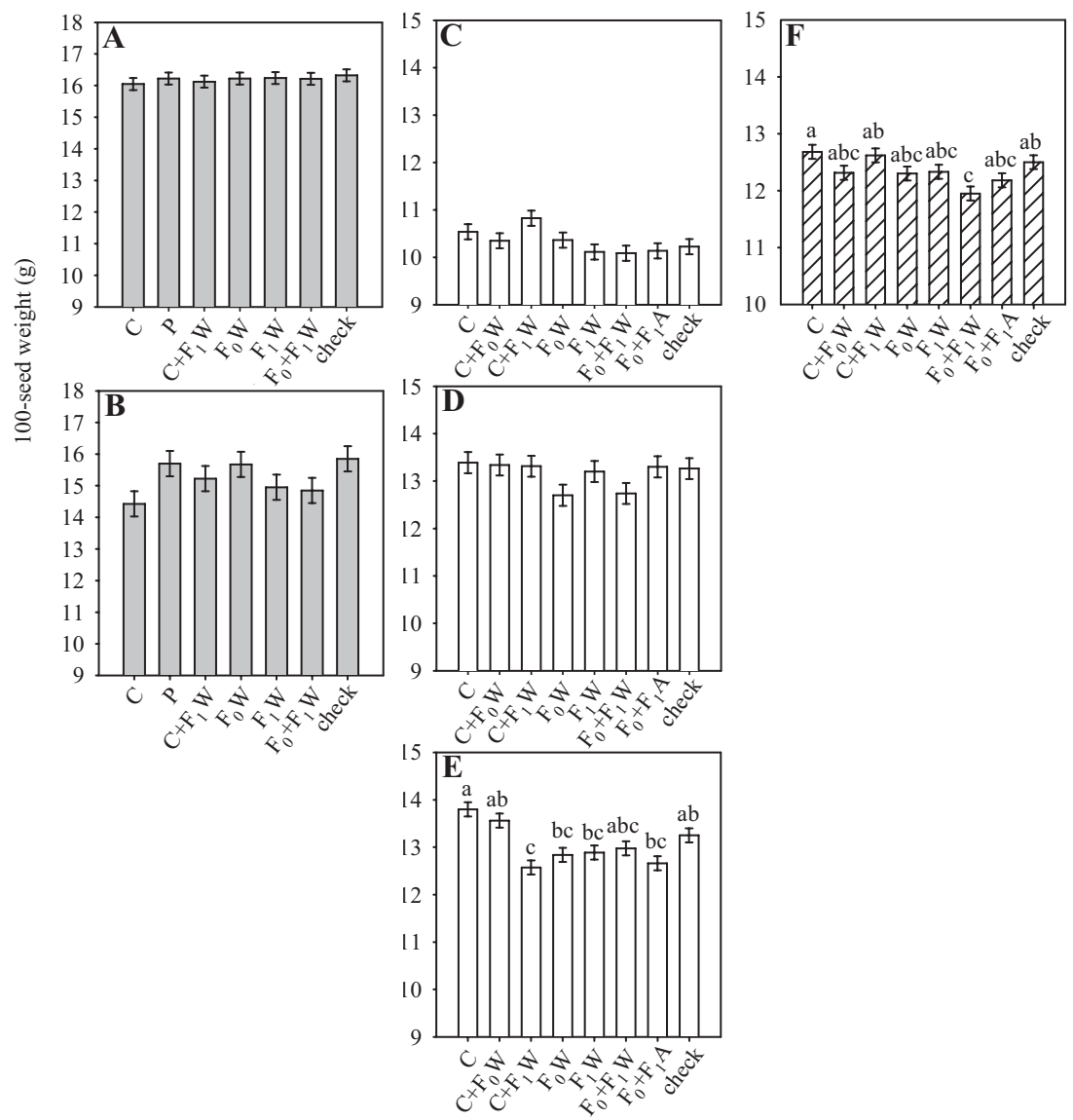

Fig. 9. Mean \pm SE 100-seed weight (g) of soybean seeds harvested from experiments to reduce C. trifurcata abundance and BPMV incidence in 2002 (gray bars), 2003 (white bars), and 2004 (hatched bars). Data from central and northwest combined (A), northeast (B and D), central (C), northwest (E), and central and northeast Iowa combined (F). Treatments (2002): C, Cruiser; P, Poncho; W, Warrior; $\mathrm{F}_{0}$, early-season population target; $\mathrm{F}_{1}$, mid-season population target; check, untreated control. Treatments (2003-2004): C, Cruiser; A, Asana; W, Warrior; $\mathrm{F}_{0}$, early-season population target; $\mathrm{F}_{1}$, mid-season population target, check, untreated control. Means grouped by the same lowercase letter are not significantly different $(P<0.05)$. Data grouped by location based on significant location by treatment interactions $(P<0.05)$.

reducing the establishment of the population in endemic years (e.g., 2003 and 2004) (Table 2). Whereas, a reduction in population establishment was only significant in one treatment of one location in 2002. Therefore, during years of high C. trifurcata abundance (e.g., 2002), the onset of a large $\mathrm{F}_{1}$ vector population may be difficult to manage by insecticidal control alone. Even when seasonal population growth is greatly suppressed (Fig. 1B), the rate of transmission apparently is not sufficiently reduced to significantly improve yield (Fig. 8A) when vector populations are large.

Although not the target of the insecticide program in this study, no $\mathrm{F}_{0}$ or $\mathrm{F}_{1}$ control strategy maintained $\mathrm{F}_{2}$ populations below economic injury levels for lateseason pod damage (Fig. 5A-C) in 2002 (data not shown), based on the above-mentioned management costs and soybean market value (Lam et al. 2000). Interestingly, the $\mathrm{F}_{1}$ population would not have predicted the large abundance of $F_{2}$ beetles that occurred at the northwest location in 2002. The simple linear model proposed by Lam et al. (2001) predicts $81 \mathrm{~F}_{2}$ beetles in 2002 , based on $F_{1}$ peak abundance, whereas the observed estimate of $\mathrm{F}_{2}$ C. trifurcata at this location and year was $213.5 \pm 21.6$. The difference may indicate that this $\mathrm{F}_{2}$ population originated elsewhere. Additionally, the AUDPC remained within the damage boundary (Horn et al. 1973, Hopkins and Mueller 1984) throughout this study, yet there was a significant yield response at only two locations in 2003 and one location in 2004.

Yield was greatest for northeast and northwest locations in 2003 if both $\mathrm{F}_{0}$ and $\mathrm{F}_{1}$ populations of $C$. trifurcata were targeted (Fig. 8B). Because there was no significant effect of insecticides on the AUDPC, these yield improvements may be attributable to reductions in direct damage from C. trifurcata. Although soybean aphids were also present in 2003, their abundance peaked after the insecticide application for $\mathrm{F}_{1}$-C. trifurcata population (unpublished data) and 


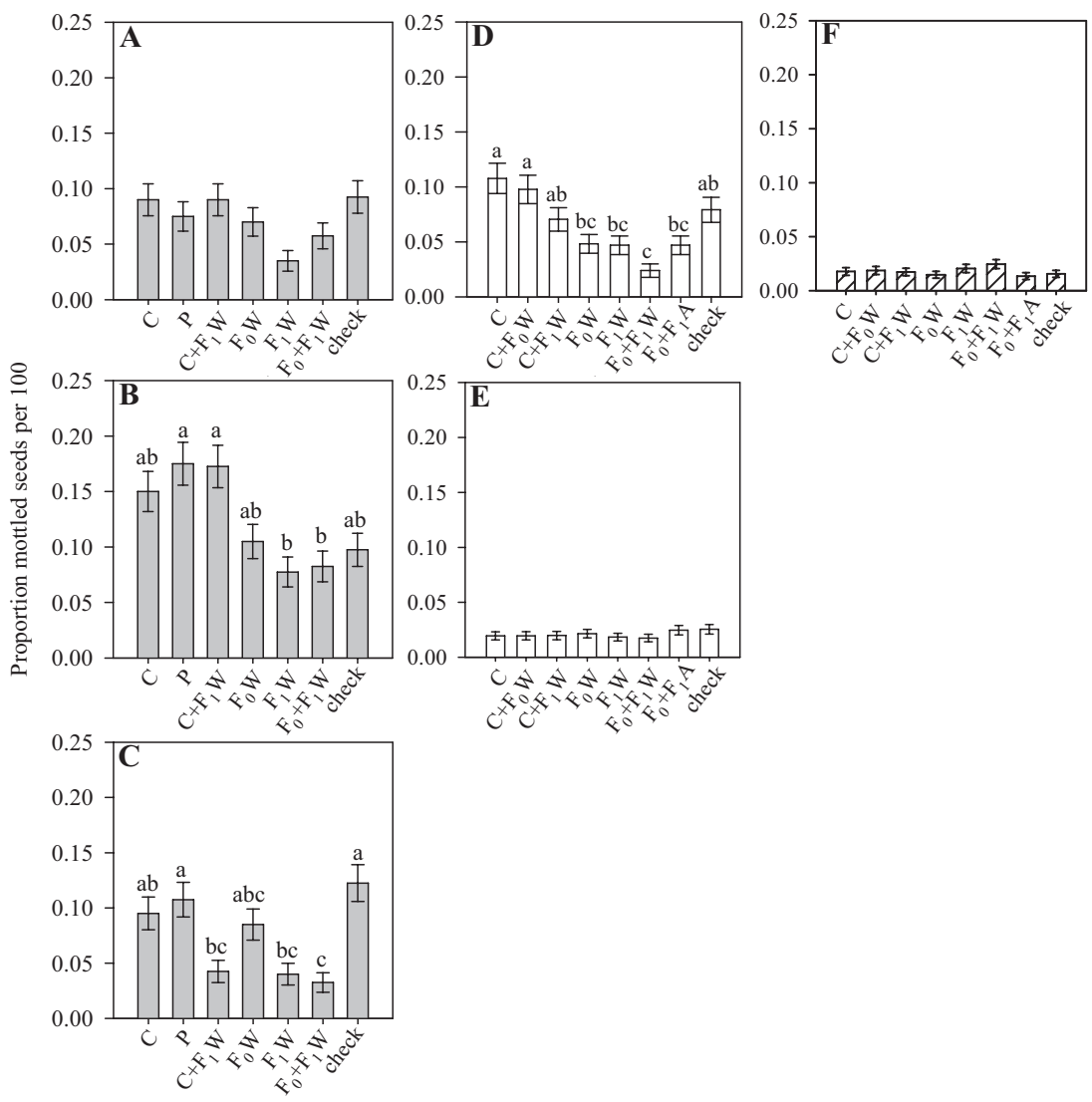

Fig. 10. Mean \pm SE percentage mottled soybean seeds in experiments to reduce C. trifurcata abundance and BPMV incidence in 2002 (gray bars), 2003 (white bars), and 2004 (hatched bars). Data from central (A), northeast (B and D), and northwest (C), central and northwest combined (E), and central and northeast Iowa combined (F). Treatments (2002): C, Cruiser; $\mathrm{P}$, Poncho; $\mathrm{W}$, Warrior; $\mathrm{F}_{0}$, early-season population target; $\mathrm{F}_{1}$; mid-season population target; check, untreated control. Treatments (2003-2004): C, Cruiser; A, Asana; W, Warrior; $\mathrm{F}_{0}$, early-season population target; $\mathrm{F}_{1}$, mid-season population target; check, untreated control. Treatment means based on one 100-seed count from each experimental unit. Means grouped by the same lowercase letter are not significantly different $(P<0.05)$. Data grouped by location based on significant location by treatment interactions $(P<0.05)$.

insecticides, as applied in this study, do not prevent economic injury from soybean aphids (Johnson et al. 2007). However, economic injury from all of these pests is likely not mutually exclusive and reductions in insect and viral pests may interact to affect soybean yield. Furthermore, a reduction in yield in response to foliar insecticide, as in the northeast location in 2004 (Fig. 8E), may be related to the suboptimal insecticide timings on soybean aphids and contributing to pest resurgence (Johnson et al. 2007).

Grain quality is an important factor in the value of soybean grown for export (USDA 2006). This study supports the findings of Krell et al. (2004) that a $\mathrm{F}_{0^{-}}+$ $\mathrm{F}_{1}$-targeted insecticide strategy (using $\lambda$-cyhalothrin for both applications) may keep grain within acceptable quality standards. However, seed-coat color is regulated by a family of genes (Takahashi and Abe 1999; Senda et al. 2002, 2004), some of which are affected by the environment. This genotype by environment interaction is variety dependent and seems to also affect the phenotypic expression of BPMV on soybean seed coats (Krell et al. 2005, Hill et al. 2007). Because of these interactions it may prove difficult to manage for soybean quality in preference for earlier planting times (Pedersen 2006) without the use of more reliable management tools.

As reviewed by Perring et al. (1999), some plant viruses can increase in incidence in response to some insecticides. Furthermore, Pederson et al. (2007) reported an increase in BPMV incidence with the use of foliar insecticides timed to suppress soybean aphid, Aphis glycines Matsumura, abundance. In this study there was no statistically significant increase in virus incidence with the use of insecticides applied to suppress C. trifurcata abundance (Fig. 6A-C). However, there was a consistent trend toward increased BPMV incidence between seed-treated plots when a foliar insecticide was added (Fig. 6A-C).

Although the dispersion pattern of $\mathrm{F}_{0}$ populations is unknown, both $\mathrm{F}_{1}$ and $\mathrm{F}_{2}$ populations of C. trifurcata have a significantly aggregated dispersion (i.e., variance to mean ratio is $>1$ ) within soybean fields (Krell 
1999). As such, the suppression of vectors by chemicals should work to reduce BPMV much like chemical controls have worked in other systems with colonizing insect vectors (Perring et al. 1999). Although the $\mathrm{F}_{2}$ population likely is not an important vector for BPMV (Giesler et al. 2002), the $F_{1}$ population is a secondary source and dispersal agent. The fact that the suppression of vectors ( $F_{0}$ or $F_{1}$ populations) did not consistently suppress BPMV in this study may indicate underappreciated behavioral effects for some chemical applications, e.g., increased movement as suggested by Pedersen et al. (2007). Future studies should evaluate the impact of insecticides on C. trifurcata dispersal as it relates the primary and secondary spread of BPMV in soybean.

There can be benefits to yield with an $\mathrm{F}_{0^{-}}+\mathrm{F}_{1^{-}}$ targeted insecticide strategy and the maximum yield gain can be achieved when a seed-applied insecticide is used as the $\mathrm{F}_{0}$-targeted insecticide (Fig. 8B). However, these yield benefits may be offset under some situations with poorly colored grain when a seedapplied insecticide is used (Fig. 9D). Because the success of this management program depends on the seasonal dynamics of $C$. trifurcata, consistent suppression of both $C$. trifurcata and BPMV is challenging; therefore, caution should be taken in its recommendation. These results further clarify the need to discover and exploit the mechanisms of resistance to $C$. trifucata and BPMV.

\section{Acknowledgments}

We thank A. Eggenberger and M. Reza Hajimorad for insight and suggestions concerning molecular methods; David Starrett, David Haden, and Kenneth Pecinovski for field management activities; and Larry Pedigo and two anonymous reviewers for constructive comments on the manuscript. This research was funded in part by the Iowa Soybean Association and the North Central Soybean Research Program. This journal paper of the Iowa Agriculture and Home Economics Experiment Station, Ames, IA, Project 3608, was supported, in part, by Hatch Act and State of Iowa funds.

\section{References Cited}

Anjos, J. R., U. Jarlfors, and S. A. Ghabrial. 1992. Soybean mosaic potyvirus enhances the titer of two comoviruses in dually infected soybean plants. Phytopathology 82: 1022-1027.

Bayer CropScience. 2006. Poncho ${ }^{\mathrm{TM}}$ 600. Material safety data sheet. EPA registration no. 264-789. Bayer CropScience, Monheim am Rhein, Germany.

Bayer CropScience. 2007. Gaucho ${ }^{\circledR} 480$ Flowable. Material safety data sheet. EPA registration no. 264-957. Bayer CropScience, Monheim am Rhein, Germany.

Boyd, M. L., and D. J. Boethel. 1998. Residual toxicity of selected insecticides to heteropteran predaceous species (Heteroptera: Lygaeidae, Nabidae, Pentatomidae) on soybean. Environ. Entomol. 27: 154-160.

Bradshaw, J. D., and M. E. Rice. 2003. Bean leaf beetle: a current and historical perspective. Integrated Crop Management IC-490: 20-21. Iowa State University, Ames, IA.

Bradshaw, J. D., M. E. Rice, and J. H. Hill. 2007. No-choice preference of Cerotoma trifurcata (Coleoptera: Chry- somelidae) to potential host plants of bean pod mottle virus (Comoviridae) in Iowa. J. Econ. Entomol. 100: 808 814.

Chapman, R. F. 1998. Muscles, pp. 229-255. In R. F. Chapman [ed.], The insects: structure and function. Cambridge University Press, Cambridge, United Kingdom.

Daniels, J. L. 2004. The epidemiology and management of the soybean seed discoloration syndrome associated with bean pod mottle virus. M.S. thesis, Iowa State University, Ames.

Dobrin, G. C., and R. B. Hammond. 1985. The antifeeding activity of selected pyrethroids towards the Mexican bean beetle (Coleoptera, Coccinellidae). J. Kans. Entomol. Soc. 58: 422-427.

Fehr, W. R., C. E. Caviness, D. T. Burmood, and J. S. Pennington. 1971. Stage of development descriptions for soybeans, Glycine max (L.) Merrill. Crop Sci. 11: 929-931.

Fulton, J. P., and H. A. Scott. 1974. Virus-vectoring efficiencies of two species of leaf-feeding beetles. Proc. Am. Phytopathol. Soc. 1: 159.

Giesler, L. J., S. A. Ghabrial, T. E. Hunt, and J. H. Hill. 2002. Bean pod mottle virus: a threat to US soybean production. Plant Dis. 86: 1280-1289.

Hammond, R. B. 1996. Residual activity of lambda-cyhalothrin against bean leaf beetle (Coleoptera: Chrysomelidae) in soybeans. J. Agric. Entomol. 13: 365-373.

Hammond, R. B., P. Bierman, E. Levine, and R. L. Cooper. 2001. Field resistance of two soybean germplasm lines, HC95-15MB and HC95-24MB, against bean leaf beetle (Coleoptera: Chrysomelidae), western corn rootworm (Coleoptera: Chrysomelidae), and Japanese beetles (Coleoptera: Scarabaidae). J. Econ. Entomol. 94: 1594-1601.

Henn, T. 1989. Analysis of bean leaf beetle feeding behavior in dual-choice preference testing of legumes. M.S. thesis, University of Illinois, Urbana.

Hill, J. H., N. C. Koval, J. M. Gaska, and C. R. Grau. 2007. Identification of field tolerance to bean pod mottle and soybean mosaic viruses in soybean. Crop Sci. 47: 212-218.

Hopkins, J. D., and A. J. Mueller. 1984. Effect of bean pod mottle virus on soybean yield. J. Econ. Entomol. 77: 943947.

Horn, H. L., L. D. Newsom, R. G. Carver, and R. L. Jensen. 1970. Effects of virus diseases on soybeans in Louisiana. LA Agric. 13: 12-15.

Horn, H. L., L. D. Newsom, R. G. Carver, and R. L. Jensen. 1973. Economic injury thresholds of bean pod mottle and tobacco ringspot virus infection of soybeans. Plant Dis. Rep. 57: 811-813.

Johnson, K. D., M. E. O’Neal, J. D. Bradshaw, and M. E. Rice. 2007. Preventative concurrent management of the soybean aphid (Homoptera: Aphididae) and bean leaf beetle (Coleoptera: Chrysomelidae). J. Econ. Entomol. 101: 801-809.

Kogan, M., W. G. Ruesink, and K. McDowell. 1974. Spatial and temporal distribution patterns of the bean leaf beetle, Cerotoma trifurcata (Förster), on soybeans in Illinois. Environ. Entomol. 3: 607-617.

Krell, R. K. 1999. Potential of location-specific soybean insect management. M.S. Thesis. Iowa State Univ., Ames, IA.

Krell, R. K., L. P. Pedigo, J. H. Hill, and M. E. Rice. 2003. Potential primary inoculum sources of Bean pod mottle virus in Iowa. Plant Dis. 87: 1416-1422.

Krell, R. K., L. P. Pedigo, J. H. Hill, and M. E. Rice. 2004. Bean leaf beetle (Coleoptera: Chrysomelidae) management for reduction of bean pod mottle virus. J. Econ. Entomol. 97: 192-202. 
Krell, R. K., L. P. Pedigo, M. E. Rice, M. E. Westgate, and J. H. Hill. 2005. Using planting date to manage bean pod mottle virus in soybean. Crop Prot. 24: 909-914.

Kuel, R. O. 2000. Design of experiments: statistical principles of research design and analysis. Duxbury Press, Pacific Grove, CA.

Lam, W.-K. F., and L. P. Pedigo. 2000. A predictive model for the survival of overwintering bean leaf beetles (Coleoptera: Chrysomelidae). Environ. Entomol. 29: 800806.

Lam, W.-K. F., M. E. Rice, L. P. Pedigo, and R. O. Pope. 2000. New concept for bean leaf beetle management. Integrated Crop Management 484: 125-127. Iowa State University, Ames.

Lam, W.-K. F., L. P. Pedigo, and P. N. Hinz. 2001. Population dynamics of bean leaf beetles (Coleoptera: Chrysomelidae) in central Iowa. Environ. Entomol. 30: 562-567.

Lam, W.-K. F., and L. P. Pedigo. 2001. Effect of trichome density on soybean pod feeding by adult bean leaf beetles (Coleoptera: Chrysomelidae). J. Econ. Entomol. 94: 1459-1463.

Mabry, T. R., H. A. Hobbs, T. A. Steinlage, B. B. Johnson, W. L. Pedersen, J. L. Spencer, E. Levine, S. A. Isard, L. L. Domier, and G. L. Hartman. 2003. Distribution of leaffeeding beetles and bean pod mottle virus (BPMV) in Illinois and transmission of BPMV in soybean. Plant Dis. 87: 1221-1225.

Moore, B. J., H. A. Scott, and H. J. Walters. 1969. Desmodium paniculatum, a perennial host of bean pod mottle virus in nature. Plant Dis. Rep. 53: 154-155.

Patel, V. C., and H. N. Pitre. 1971. Transmission of bean pod mottle virus to soybean by the striped blister beetle, Epicauta vittata. Plant Dis. Rep. 55: 628-629.

Patel, V.C., and H. N. Pitre. 1976. Transmission of bean pod mottle virus by bean leaf beetle and mechanical inoculation to soybeans at different stages of growth. J. Ga. Entomol. Soc. 11: 289-293.

Pedersen, P. 2006. Soybean planting date. Integrated Crop Management 496: 68. Iowa State University, Ames.

Pedersen, P., C. R. Grau, E. M. Cullen, N. C. Koval, and J. H Hill. 2007. Potential for integrated management of soybean virus disease. Plant Dis. 91: 1255-1259.

Pedigo, L. P., and M. R. Zeiss. 1996. Effect of soybean planting date on bean leaf beetle (Coleoptera: Chrysomelidae) abundance and pod injury. J. Econ. Entomol. 89: 183-188.

Pedigo, L. P., and M. E. Rice. 2006. Entomology and pest management, 5th ed. Pearson Prentice Hall, Upper Saddle River, NJ.

Perring, T. M., N. M. Gruenhagen, and C. A. Farrar. 1999. Management of plant viral diseases through chemical control of insect vectors. Annu. Rev. Entomol. 44: 457481.

Quiniones, S. S., J. M. Dunleavy, and J. W. Fisher. 1971. Performance of three soybean varieties inoculated with soybean mosaic virus and bean pod mottle virus. Crop Sci. 11: $662-664$.

Ragsdale, D. W. 1984. Bean pod mottle virus and soybean yield: effects of inoculation date and infection rate, pp. 46, Program and Abstracts World Soybean Research Conference-III. Iowa State University, Ames, IA.

Reddy, M. S., P. Srinivas, S. A. Ghabrial, C. T. Redmond, R. D. Dinkins, and G. B. Collins. 2001. Resistance to bean pod mottle virus in transgenic soybean lines expressing the capsid polyprotein. Phytopathology 91: 831-838.
Rice, M. E., and R. Pope. 2004. Bean leaf beetle mortality in winter: 2003 vs. 2004. Integrated Crop Management 492: 29-30. Iowa State University, Ames.

Rice, M. E., and M. O’Neal. 2007. Soybean insecticides for 2007. Integrated Crop Management 498: 79-80. Iowa State University, Ames.

Rice, M. E., J. D. Bradshaw, and J. H. Hill. 2007. Revisiting an integrated approach to bean leaf beetle and bean pod mottle virus management. Integrated Crop Management 498: 87-88. Iowa State University, Ames.

Robertson, A., and F. W. Nutter. 2006. Iowa soybean disease survey, Iowa State University, Ames, IA. (http://www. plantpath.iastate.edu/soybeansurvey/node/7).

Ross, J. P. 1968. Effect of single and double infections of soybean mosaic and bean pod mottle viruses on soybean yield and seed characters. Plant Dis. Rep. 52: 344-348.

Ross, J. P. 1969. Effect of time and sequence of inoculation of soybeans with soybean mosaic and bean pod mottle viruses on yields and seed characters. Phytopathology 59: 1404-1408.

SAS Institute. 2006. SAS 9.1.3 help and documentation. SAS Institute, Cary, NC.

Senda, M., A. Jumonji, S. Yumoto, R. Ishikawa, T. Harada, M. Niizeki, and S. Akada. 2002. Analysis of the duplicated CHS1 gene related to the suppression of the seed coat pigmentation in yellow soybeans. Theor. Appl. Genet. 104: 1086-1091.

Senda, M., C. Masuta, S. Ohnishi, K. Goto, A. Kasai, T. Sano, J.-S. Hong, and S. MacFarlane. 2004. Patterning of virusinfected Glycine max seed coat is associated with suppression of endogenous silencing of chalcone synthase genes. Plant Cell 16: 807-818.

Smelser, R. B., and L. P. Pedigo. 1991. Phenology of Cerotoma trifurcata on soybean and alfalfa in central Iowa. Environ. Entomol. 20: 514-519.

Smelser, R. B., and L. P. Pedigo. 1992a. Bean leaf beetle (Coleoptera: Chrysomelidae) herbivory on leaf, stem, and pod components of soybean. J. Econ. Entomol. 85: 2408-2412.

Smelser, R. B., and L. P. Pedigo. 1992b. Soybean seed yield and quality reduction by bean leaf beetle (Coleoptera, Chrysomelidae) pod injury. J. Econ. Entomol. 85: 23992403.

Srinivas, P., S. D. Danielson, C. M. Smith, and J. E. Foster. 2001. Induced resistance to bean leaf beetle (Coleoptera: Chrysomelidae) in soybean. J. Entomol. Sci. 36: 438-444.

Steinlage, T. A., J. H. Hill, and F. W. Nutter. 2002. Temporal and spatial spread of Soybean Mosaic Virus (SMV) in soybeans transformed with the coat protein gene of SMV. Phytopathology 92: 478-486.

Syngenta Crop Protection Inc. 2005. Cruiser 5FS. Material safety data sheet. EPA registration no. 100-941. Syngenta Crop Protection Inc., Greensboro, NC.

Takahashi, R., and J. Abe. 1999. Soybean maturity genes associated with seed coat pigmentation and cracking in response to low temperatures. Crop Sci. 39: 1657-1662.

[USDA] United States Department of Agriculture. 2006. United States standards for soybeans. Grain Inspection, Packers \& Stockyards Administration. Fed. Regist. 71: 52403-52406.

Waldbauer, G. P., and M. Kogan. 1976. Bean leaf beetle: phenological relationship with soybean in Illinois. Environ. Entomol. 5: 35-44.

Walters, H. J. 1970. Bean pod mottle virus disease of soybeans. Arkans. Farm Res. 19: 8 .

Wang, R. Y., R. C. Gergerich, and K. S. Kim. 1992. Noncir- 
culative transmission of plant-viruses by leaf-feeding beetles. Phytopathology 82: 946-950.

Werner, B. J., R. K. Krell, L. P. Pedigo, and J. H. Hill. 2003.

The soybean leaf miner (Coleoptera: Chrysomelidae) as a vector of bean pod mottle virus. J. Kans. Entomol. Soc. 76: 643-644.
Witkowski, J. F., and G. W. Echtenkamp. 1996. Influence of planting date and insecticide on the bean leaf beetle (Coleoptera: Chrysomelidae) abundance and damage in Nebraska soybean. J. Econ. Entomol. 89: 189-196.

Received 12 November 2007; accepted 21 February 2008 